\title{
Sex-specific DNA methylation differences in Alzheimer's disease pathology
}

Lanyu Zhang ${ }^{1}$, Juan I. Young ${ }^{2,3}$, Lissette Gomez ${ }^{3}$, Tiago C. Silva ${ }^{1}$, Michael A. Schmidt ${ }^{2,3}$, Jesse Cai ${ }^{4}$, Xi Chen ${ }^{1,5}$, Eden R. Martin ${ }^{2,3}$ and Lily Wang ${ }^{1,2,3,5^{*}}$ (1)

\begin{abstract}
Sex is an important factor that contributes to the clinical and biological heterogeneities in Alzheimer's disease $(A D)$, but the regulatory mechanisms underlying sex disparity in AD are still not well understood. DNA methylation is an important epigenetic modification that regulates gene transcription and is known to be involved in AD. We performed the first large-scale sex-specific meta-analysis of DNA methylation differences in AD neuropathology, by re-analyzing four recent epigenome-wide association studies totaling more than 1000 postmortem prefrontal cortex brain samples using a uniform analytical pipeline. For each cohort, we employed two complementary analytical strategies, a sex-stratified analysis that examined methylation-Braak stage associations in male and female samples separately, and a sex-by-Braak stage interaction analysis that compared the magnitude of these associations between different sexes. Our analysis uncovered 14 novel CpGs, mapped to genes such as TMEM39A and TNXB that are associated with the AD Braak stage in a sex-specific manner. TMEM $39 A$ is known to be involved in inflammation, dysregulated type I interferon responses, and other immune processes. TNXB encodes tenascin proteins, which are extracellular matrix glycoproteins demonstrated to modulate synaptic plasticity in the brain. Moreover, for many previously implicated genes in AD neuropathology, such as MBP and AZU1, our analysis provided the new insights that they were predominately driven by effects in only one sex. These sex-specific DNA methylation differences were enriched in divergent biological processes such as integrin activation in females and complement activation in males. Our study implicated multiple new loci and biological processes that affected AD neuropathology in a sex-specific manner.
\end{abstract}

Keywords: Alzheimer's disease, Sex-specific, DNA methylation, Epigenome-wide association study

\section{Introduction}

Late-onset Alzheimer's disease (LOAD) is the most common cause of dementia. With the aging population in the U.S., Alzheimer's disease (AD) has become a major public health concern and one of the most financially costly diseases [1]. Almost two-thirds of AD patients in the U.S. are women [2]. After diagnosis, women also progress faster with more rapid cognitive and functional declines

*Correspondence: lily.wangg@gmail.com

${ }^{1}$ Division of Biostatistics, Department of Public Health Sciences, University of Miami, Miller School of Medicine, Miami, FL 33136, USA

Full list of author information is available at the end of the article
[3-8]. On the other hand, it has also been reported men with $\mathrm{AD}$ have an increased risk for death [9-11]. However, the molecular mechanisms underlying these observed disparities in AD are still not well understood. Previous studies have shown that epigenetics is an important contributor to the sex differences in brain functions and vulnerability to diseases [12-16]. Among epigenetic modifications, DNA methylation profiles differ significantly between males and females at many loci in adult brains [17]. Importantly, alterations of DNA methylation levels have also been implicated in multiple neurological disorders including $\mathrm{AD}[18-22]$. original author(s) and the source, provide a link to the Creative Commons licence, and indicate if changes were made. The images or other third party material in this article are included in the article's Creative Commons licence, unless indicated otherwise in a credit line to the material. If material is not included in the article's Creative Commons licence and your intended use is not permitted by statutory regulation or exceeds the permitted use, you will need to obtain permission directly from the copyright holder. To view a copy of this licence, visit http://creativecommons.org/licenses/by/4.0/. The Creative Commons Public Domain Dedication waiver (http://creativeco mmons.org/publicdomain/zero/1.0/) applies to the data made available in this article, unless otherwise stated in a credit line to the data. 
However, thus far, a comprehensive characterization for the contribution of sex to DNA methylation differences in AD neuropathology has not been performed. In the identification of sex-specific effects, statistical power is a major challenge [23]. Stratifying by sex reduces the sample size of both groups. Also, comparing methylation to disease associations between the sexes by testing the interaction effect would require a much larger sample size than detecting the main effect with the same magnitude [24]. To address these challenges, we performed a comprehensive meta-analysis of more than 1000 postmortem brain prefrontal cortex (PFC) samples, collected from four recent $\mathrm{AD}$ epigenome-wide association studies [18-21], to identify the most consistent DNA methylation differences affected by AD neuropathology in a sex-specific manner. Within each cohort, to identify sexspecific differences in AD neuropathology, we employed two complementary approaches, a sex-stratified analysis that examined methylation-Braak stage associations in female and male samples separately, and a sex-by-Braak stage interaction analysis that compared the magnitude of these associations between different sexes. As sex is a strong factor in driving inter-personal variabilities in AD, the results of this study are particularly relevant for precision medicine.

\section{Methods}

\section{Study cohorts}

Our meta-analysis included 1,030 prefrontal cortex brain samples (642 female samples and 388 male samples) from four independent cohorts (Additional file 2: Table S1), previously described in the ROSMAP [18], Mt. Sinai [20], London [19], and Gasparoni [21] DNA methylation studies.

\section{Pre-processing of DNA methylation data}

All the samples in this study were measured using the Infinium HumanMethylation450 BeadChip. Additional file 2: Table S2 shows the number of CpGs and samples removed at each quality control step. Quality control for CpG probes included removing probes with detection $\mathrm{P}$-value $<0.01$ in all samples of a cohort using the minfi $R$ package, removing the 2623 CpGs associated with cigarette smoking identified in Joehanes et al. [25] (at $\mathrm{P}$-value $<1 \times 10^{-7}$ threshold), and removing $\mathrm{CpGs}$ having a single nucleotide polymorphism (SNP) with minor allele frequency $(\mathrm{MAF}) \geq 0.01$ present in the last 5 base pairs of the probe using the DMRcate $\mathrm{R}$ package (with function $\mathrm{rmSNPandCH}$ and option dist $=5$, mafcut $=0.01$ ). For the quality control of samples, we removed samples with low bisulfite conversion efficiency (i.e., $<88 \%$ ) or detected as outliers in principal component analysis (PCA). More specifically, PCA was performed using the 50,000 most variable CpGs for each cohort. Samples that were within \pm 3 standard deviations from the means of PC1 and PC2 were selected to be included in the final sample set. The quality-controlled methylation datasets were next subjected to the QN.BMIQ normalization procedure as recommended by a recent systematic study of different normalization methods [26]. More specifically, we first applied quantile normalization as implemented in the lumi $\mathrm{R}$ package to remove systematic effects between samples. Next, we applied the $\beta$-mixture quantile normalization (BMIQ) procedure [27] as implemented in the wateRmelon $R$ package [28] to normalize beta values of type 1 and type 2 design probes within the Illumina arrays. Finally, to remove batch effects, we applied the linear model methylation $M$ value methylation slide to $M$ values of each CpG. The methylation residuals from these linear models were then used for subsequent analysis.

\section{Single cohort analysis}

To identify sex-specific DNA methylation differences in AD neuropathology, we performed both a sex-stratified analysis and a sex-by-Braak stage interaction analysis for each of the four brain sample cohorts. In the sexstratified analysis, we tested methylation-Braak stage associations in female and male samples separately. In sex-by-Braak stage interaction analysis, we analyzed both female and male samples simultaneously and compared slopes for methylation-Braak stage associations in females and males.

More specifically, in the sex-stratified analysis, for each CpG, we applied the model methylation residuals $\sim$ age at death + Braak stage + estimated neuron proportions to female samples and male samples separately, where methylation residuals were obtained in "Pre-processing of DNA methylation data" described above. Here, the neuron proportion for each sample was estimated using the CETS R package [29], an R software that quantifies neuronal proportions from DNA methylation data using cell epigenotype specific (CETS) marks. In sex-by-Braak stage interaction analysis, for each $\mathrm{CpG}$, we applied the model methylation residuals $\sim$ age at death + sex + Braak stage + sex*Braak stage + sex*age at death + estimated neuron proportions to samples including both sexes.

For the analysis of differentially methylated regions (DMRs), we used the coMethDMR R package [30] to analyze 40,010 pre-defined genomic regions on the Illumina $450 \mathrm{k}$ arrays and identify co-methylated DMRs associated with Braak stage. The pre-defined genomic regions are regions on the Illumina array covered with clusters of contiguous CpGs where the maximum separation between any two consecutive probes is 200 base pairs. First, coMethDMR selects co-methylated regions within 
these pre-defined contiguous genomic regions. Next, we summarized methylation $\mathrm{M}$ values within these co-methylated regions using medians and tested them against the AD Braak stage. The same linear models described for the analysis of CpGs were then applied to the median value of each DMR. We considered CpGs (or DMRs) with a false discovery rate (FDR) less than 0.05 in female samples or male samples to be significant.

\section{Inflation assessment and correction}

For genome-wide discoveries to be valid, the false positive rate of the study should be properly controlled. Because systematic inflation of test statistics can lead to an increase in the number of false-positive results, traditionally genomic inflation factor [31] is typically used to quantify the amount of inflation in genome-wide association studies (GWAS) of genetic variants. However, as shown by simulation studies [32], real datasets [32], and theory [31], the conventional genomic inflation factor (lambda or $\lambda$ used interchangeably below) is dependent on the expected number of true associations. Because in a typical epigenome-wide association study (EWAS), it is expected that small effects from many CpGs might be associated with the phenotype, the genomic inflation factor would overestimate actual test-statistic inflation. To estimate genomic inflations more accurately in EWAS, Iterson et al. [32] developed a Bayesian method that estimates inflation in EWAS based on empirical null distributions, which is implemented in the Bioconductor package bacon.

In this study, to assess inflation of the test statistics, we used quantile-quantile (QQ) plots and estimated genomic inflation factors using both the conventional approach and the bacon method [32] (Additional file 1: Fig. S1). The bacon method was also used to obtain inflation-corrected effect sizes, standard errors, and P-values for each cohort, which were then combined by inversevariance weighted meta-analysis models using $R$ package meta.

\section{Meta-analysis}

The evidence for heterogeneity of study effects was tested using Cochran's Q statistic [33]. The inverse-variance weighted fixed effects model was first applied to synthesize statistical significance from individual cohorts. Even though the fixed effects model for meta-analysis does not require the assumption of homogeneity [34], for the CpGs (or genomic regions) with nominal evidence for heterogeneity (nominal $\mathrm{P}_{\text {heterogeneity }}<0.05$ ), we also applied random effects meta-analysis [35] and assigned final meta-analysis P-value based on the random effects model. For each CpG (and for each genomic region), we used the $\mathrm{R}$ package meta to obtain Braak stage effect in female samples and male samples separately in sex-stratified analysis, as well as meta-analysis P-values for sex-byBraak stage interaction.

\section{Identifying sex-specific differences}

In the sex-stratified analysis, we selected significant CpGs (or genomic regions) with FDR $<0.05$ in female samples or male samples separately. In sex-by-Braak stage interaction analysis, because the standard error of interaction effect sex $\times$ Braak stage is typically much larger than those for main Braak stage effects, the conventional approach for controlling false discovery rate often results in low power for discovering interaction effects [36]. Therefore, we used a stagewise analysis approach, previously proposed by van de Berge et al. (2017) [36], to help improve power in high-throughput experiments where multiple hypotheses are tested for each gene. More specifically, in the screening step, for each CpG (or genomic region), we tested the global null hypothesis that there is methylation-Braak stage association in either male or female samples. Next, in the confirmation step, we considered three individual null hypotheses for each CpG (or DMR): (a) there is no methylation-Braak stage association in male samples, (b) there is no methylation-Braak stage association in female samples, and (c) the methylation-Braak stage associations in male samples and female samples are the same. For the CpGs (or genomic region) selected in the screening step, these three individual hypotheses were then tested while controlling familywise error rate (FWER) as described in van de Berge et al. (2017)[36].

The stagewise analysis described above was implemented using the stageR package to identify CpGs (or genomic regions) with significant differential methylation-Braak stage associations in females and males. In the screening step, we considered meta-analysis P-values for the Braak stage in female samples and male samples (p.meta.female, p.meta.male), and used the minimum of these two meta-analysis P-values to represent each CpG (or genomic region). In the confirmation step, the parameter pConfirmation was defined using three P-values for each CpG (or genomic region): p.meta.female, p.meta. male, and p.meta.interaction (meta-analysis P-value for sex $\times$ Braak stage).

\section{Enrichment and pathway analysis}

The probes on the Illumina $450 \mathrm{k}$ array are annotated according to their locations with respect to genes (TSS1500, TSS200, 5'UTR, 1stExon, gene body, 3'UTR, intergenic) or CpG islands (island, shore, shelf, open sea). To understand the genomic context of sex-specific DNA methylation differences in AD neuropathology, we compared the FDR significant methylation differences from 
sex-stratified analysis with different types of genomic features. As Braak-associated methylation differences can occur at both significant individual CpGs and significant DMRs, we considered the CpGs located at significant individual CpGs or within significant DMRs jointly in this analysis, by testing their over- and under-representation in different types of genomic features using Fisher's exact test. More specifically, the proportion of significant CpGs mapped to a particular type of genomic feature (e.g., CpG islands) (foreground) was compared to the proportion of $\mathrm{CpGs}$ on the array that mapped to the same type of genomic feature (background).

Also, we used Fisher's test to assess enrichment of significant CpGs and DMRs in different chromatin states by comparing with the 15-chromatin state data for bulk PFC tissue samples (E073) from the Roadmap Epigenomics Project [37]. Using combinations of histone modification marks, ChromHMM [38] was previously used to annotate segments of the genome with different chromatin states (repressed, poised, and active promoters, strong and weak enhancers, putative insulators, transcribed regions, and large-scale repressed and inactive domains), which were shown to vary across sex, tissue type, and developmental age [39]. Similarly, we tested enrichment of significant CpGs and DMRs in binding sites of transcription factors and chromatin proteins from the ENCODE project [40] and CODEX database [41] using Locus Overlap Analysis as implemented in the LOLA R package [42].

Finally, we performed pathway analysis by comparing the genes with significant DNA methylation differences in AD neuropathology (identified in sex-stratified analysis) with the canonical pathways and biological process GO terms in MSigDB using Gene Set Enrichment Analysis (GSEA) [43]. First, we linked each CpG and each predefined genomic region tested in DMR analysis to genes by annotating them using the GREAT (Genomic Regions Enrichment of Annotations Tool) software, which associates genomic regions to target genes. With the default "Basal plus method", GREAT links each gene to a regulatory region consisting of a basal domain that extends $5 \mathrm{~kb}$ upstream and $1 \mathrm{~kb}$ downstream from its transcription start site, and an extension up to the basal regulatory region of the nearest upstream and downstream genes within $1 \mathrm{Mb}$ [44]. Next, we represented each gene by the smallest $\mathrm{P}$-value if there are multiple $\mathrm{CpGs}$ or genomic regions associated with them. To remove selection bias due to different numbers of $\mathrm{CpGs}$ or genomic regions associated with each gene (i.e., the smallest P-value for a gene with many CpGs or genomic regions linked to it is likely to be smaller than the smallest P-value for a gene with only a few linked CpGs or genomic regions), we next fit a generalized additive model [45] using the $\mathrm{R}$ package mgcv: $Y_{i} \sim f\left(\right.$ n.links $\left._{i}\right)$ where $Y_{i}$ is negative log (base 10) transformation of the smallest P-value for gene $i$ in the analysis of female samples (or male samples), n.links $s_{i}$ is the number of CpGs or genomic regions linked to gene $i$, and $f$ is a penalized spline function. We assumed gamma distribution for $Y_{i}$, as under the null hypothesis of no association, $Y_{i}$ follows the chi-square distribution (a special case of gamma distribution). The residuals from this model were estimated and used to generate a ranked gene list, which was then used as input for GSEA (in preranked mode) to identify canonical pathways and gene ontology terms (MsigDB C2:CP and C5:BP collections of gene sets) enriched with significant methylation differences in female samples and male samples separately.

\section{Integrative methylation and gene expression analysis}

To systematically evaluate transcriptional differences near the observed sex-specific DNA methylation differences, we next performed integrative methylation-gene expression analysis using data on 333 female samples and 196 male samples from the ROSMAP study with matched DNA methylation and RNA-seq gene expression profiles measured on the prefrontal cortex. To this end, normalized FPKM (Fragments Per Kilobase of transcript per Million mapped reads) gene expression values for the ROSMAP study were downloaded from the AMPAD Knowledge Portal (Synapse ID: syn3388564).

First, we linked significant CpGs (or DMRs) to nearby genes using GREAT [44], which associates genomic regions to target genes. Next, we removed confounding effects in DNA methylation data by fitting the model methylation $M$ value $\sim$ neuron.proportion + batch + sample.plate + ageAtDeath and extracting residuals from this model; these are the ROSMAP methylation residuals. Similarly, we also removed potential confounding effects in RNA-seq data by fitting model log2(normalized FPKM values +1$) \sim$ ageAtDeath + markers for cell types. The last term, "markers for cell types," included multiple covariate variables to adjust for the multiple types of cells in the brain samples. More specifically, we estimated expression levels of genes that are specific for the five main cell types present in the CNS: ENO2 for neurons, GFAP for astrocytes, CD68 for microglia, OLIG2 for oligodendrocytes, and CD34 for endothelial cells, and included these as variables in the above linear regression model, as in previous large study of AD samples [18]. The residuals extracted from this model are the ROSMAP gene expression residuals.

Finally, for each gene expression and CpG (or DMR) pair, we then tested the association between gene expression residuals and methylation residuals using a linear model: ROSAMP gene expression residuals $\sim$ ROSMAP methylation residuals + Braak stage. For significant 
DMRs, this analysis was repeated, except that methylation $M$ value was replaced with median methylation $M$ value from multiple CpGs in the DMR.

\section{Sex-specific mQTL analysis}

To identify methylation quantitative trait loci (mQTLs) for the significant DMRs and CpGs, we tested associations between the methylation levels with nearby SNPs, using the ROSMAP study dataset, which had matched genotype data and DNA methylation data for 434 female samples and 254 male samples. The ROSMAP genotype data was downloaded from AMP-AD (syn3157325) and imputed to the Haplotype Reference Consortium r1.1 reference panel [46]. There were two batches of genotype data, measured by Affymetrix GeneChip 6.0 (Affymetrix, Inc, Santa Clara, CA, USA) and Illumina HumanOmniExpress (Illumina, Inc, San Diego, CA, USA).

The male samples and female samples were analyzed separately. To reduce the number of tests, we focused on identifying cis mQTLs located within $500 \mathrm{~kb}$ from the start or end of the DMR (or position of the significant CpG) [47]. We additionally required SNPs to (1) have a minor allele frequency of at least $1 \%$, (2) be imputed with good certainty: information metric (info score) $\geq 0.4$, and (3) be associated with AD case-control status (as determined by clinical consensus diagnosis of cognitive status), after adjusting for age, batch, and the first 3 PCs estimated from genotype data, at nominal P-value less than 0.05. Next, for the ROSMAP methylation residuals obtained in section "Integrative methylation-gene expression analysis", we fit the linear model ROSMAP methylation residual $\sim$ SNP dosage + batch $+\mathrm{PC} 1+\mathrm{PC} 2+\mathrm{PC} 3$, where $\mathrm{PC} 1, \mathrm{PC} 2$, and PC3 are the first three PCs estimated from genotype data, to test the association between methylation residuals in CpGs and the imputed allele dosages for SNPs to identify mQTLs. The analysis for DMRs was the same except that we replaced ROSMAP methylation residual with median (ROSMAP methylation residuals) of all CpGs located within the DMR. SNPs with FDR less than 0.05 in the linear model described above were considered to be significant mQTLs.

\section{Drug target analysis}

We compared our list of sex-specific DNA methylation differences with targets of drugs prescribed to $\mathrm{AD}$ patients or in the development for AD in the ChEMBL database [48] (https://www.ebi.ac.uk/chembl/). To this end, we overlapped genes mapped to significant CpGs or DMRs with the genes targeted by compounds annotated to "Alzheimer Disease" in ChEMBL.

\section{Results}

\section{Description of EWAS cohorts and data}

Among the four cohorts (Additional file 2: Table S1), the mean age at death ranged from 79.3 to 87.2 years in females and from 67.5 to 85.0 years in males. The number of CpGs and samples removed at each quality control step are presented in Additional file 2: Table 2. For females, inflation factor lambdas $(\lambda)$ by the conventional approach ranged from 1.060 to 1.154 , and lambdas based on the bacon approach [32] ( $\left.\lambda_{\text {bacon }}\right)$ ranged from 1.021 to 1.059 (Additional file 1: Fig. S1). Similarly, for males, $\lambda$ ranged from 0.906 to 1.265 , and $\lambda_{\text {bacon }}$ ranged from 0.957 to 1.114 . These values are comparable to those obtained in other recent large-scale EWAS [49].

\section{Sex-specific DNA methylation differences in AD neuropathology}

In the sex-stratified analysis, at 5\% FDR, our meta-analysis identified 381 and 76 CpGs, mapped to 245 and 51 genes in female and male samples, respectively (Fig. 1, Table 1, Additional file 2: Tables S3, S4). Similarly, at 5\% FDR, we also identified 72 and 27 DMRs, mapped to 66 and 22 genes, in female and male samples, respectively (Table 2, Additional file 2: Tables S5, S6). Among them, 3.6\% (16 out of 441 unique FDR-significant CpGs) and $12.5 \%$ (11 out of 88 unique FDR-significant DMRs) were significant in both females and males with the same direction of change. The average number of $\mathrm{CpGs}$ per DMR was $6.5 \pm 8.9$. Also, the FDR-significant methylation differences at CpGs and DMRs did not completely overlap. Only 89 out of the 381 (23.4\%) significant CpGs in females, and 13 out of the $76(17.1 \%)$ significant CpGs in males overlapped with the significant DMRs. Among all CpGs and all DMRs, the effect estimates in males and females correlated only modestly $\left(r_{\mathrm{CpG}}=0.124\right.$, $r_{\mathrm{DMR}}=0.170$, Additional file 1: Fig. S2), and about half (53\% of CpGs, $54 \%$ of DMRs) were in the same direction of change in males and females, similar to what would be expected by chance.

In sex-by-Braak stage interaction analysis, we identified significant interaction at $14 \mathrm{CpGs}$, but no significant interactions at DMRs at 5\% FDR. There was also little overlap between significant DNA methylation differences identified in sex-stratified and sex-by-Braak stage interaction analyses. Only $4 \mathrm{CpGs}$ were identified by both analyses (Table 3 ). To understand this discrepancy, note that the sex-stratified analysis detected many differences that are attenuated but might be in the same direction in one sex group compared to the other. More specifically, among the FDR-significant CpGs identified in the sex-stratified analysis, many of them (370 out of 381 significant CpGs in the analysis of female samples, and 65 out of 76 significant CpGs in the analysis 


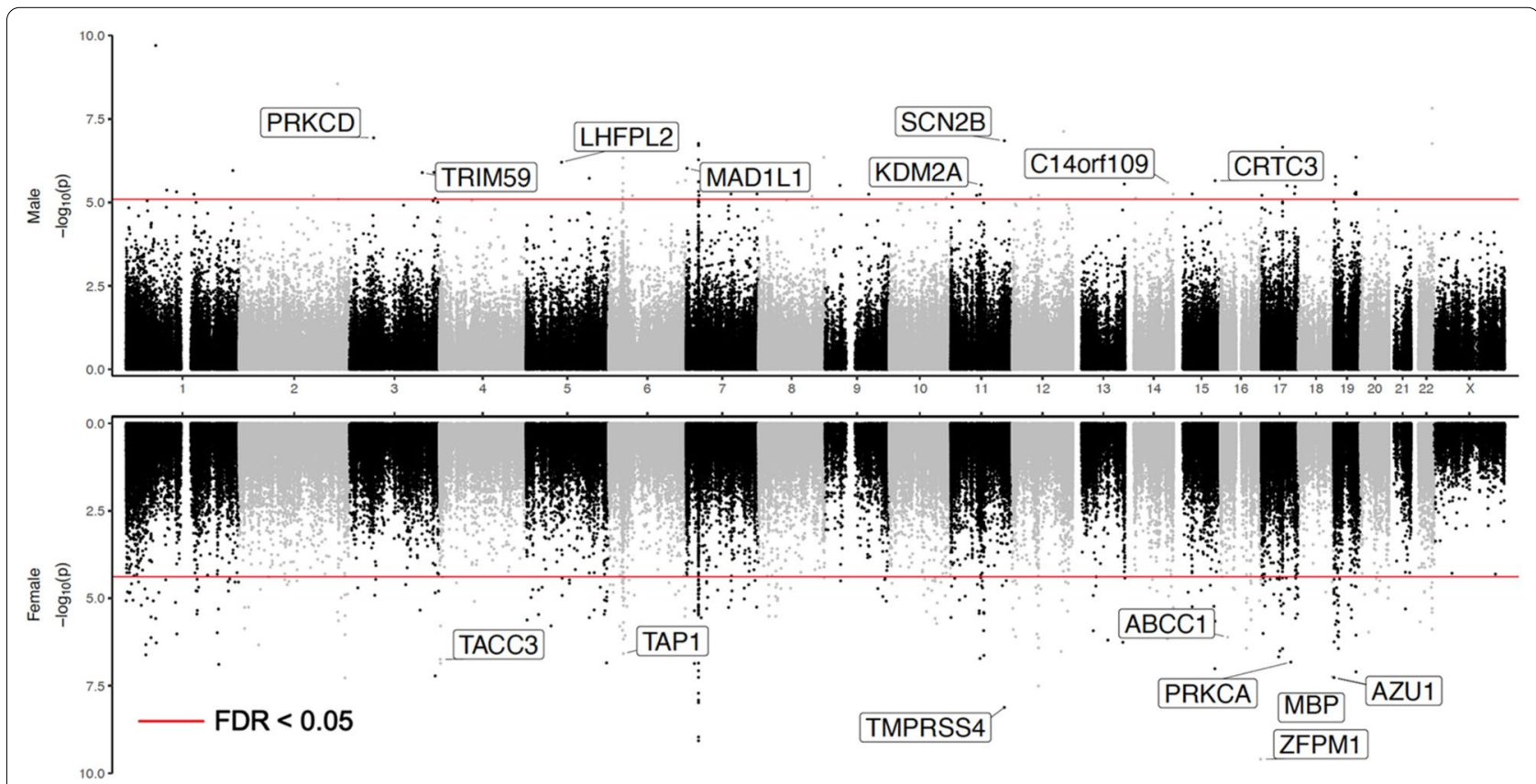

Fig. 1 Miami plot of sex-stratified analysis results. The $X$-axis are chromosome numbers. The $Y$-axis show $-\log _{10}(P$-value) of $C p G-B r a a k$ stage associations in males (above $X$-axis) or in females (below $X$-axis). The genes corresponding to top $10 \mathrm{CpGs}$ that are the most significant in one sex $(F D R<0.05)$, but not significant in another sex (P-value $>0.05)$ are highlighted

of male samples) had the same direction of change for methylation-Braak stage association in both sexes (Additional file 2: Tables S3, S4). In Table 1, among the 10 most significant CpGs from the sex-stratified analysis, 9 female-specific and 6 male-specific CpGs had the same direction of methylation-Braak stage association in both sexes. On the other hand, in sex-by-Braak stage interaction analysis, 13 out of the 14 significant CpGs had the opposite directions of differences for methylation-Braak stage associations in females and males (Table 3). Therefore, the interaction analysis was able to identify CpGs with large differences in sex-specific effect estimates, often in different directions, but these effects might not have reached FDR significance in sex-stratified analysis. For example, in Table 3, the CpG with the most significant interaction (cg13212831) had effect estimates of 0.083 and -0.139 for females and males, respectively. In sex-stratified analysis, although the methylation-Braak stage associations were highly significant $(P$-value female $=0.006$, P-valuemale $=4.1 \times 10^{-5}$ ), they did not reach $5 \%$ FDR significance threshold $\left(\mathrm{FDR}_{\text {female }}=0.413, \mathrm{FDR}_{\text {male }}=0.097\right)$. Therefore, the results from sex-stratified analysis and sex-by-Braak stage interaction analysis complemented each other.

\section{Enrichment analysis of sex-specific DNA methylation differences across genomic features}

Figure 2 presents an overview of the enrichment analysis results. Compared to background probes, significant hypermethylated DMRs and CpGs in females are overrepresented in $\mathrm{CpG}$ islands and gene bodies (Additional file 1: Fig. S3a, Additional file 2: Table S7). Significant hypermethylated DMRs and CpGs in males are over-represented in CpG island shores, 5'UTRs, and TSS1500s. In contrast, significant hypomethylated differences in females and males are over-represented in open seas (Additional file 1: Fig. S3b, Additional file 2: Table S7). These observations are consistent with the knowledge that during aging, human brain DNA methylation levels gradually increase (hypermethylation) at genomic loci located at $\mathrm{CpG}$ islands and gene promoters, whereas intergenic $\mathrm{CpG}$ sites are marked with hypomethylation $[50,51]$.

Our enrichment analysis for chromatin states showed that significant hyper-methylated differences in females were enriched in bivalent enhancer, flanking active TSS, repressed polycomb, and transcription at gene $5^{\prime}$ and $3^{\prime}$ regions (Additional file 1: Fig. S3c, Additional file 2: Table S8). On the other hand, significant hypermethylated differences in males were enriched in active TSS, flanking active TSS, and repressed polycomb regions. Hypomethylated differences in females were enriched in enhancers, weak repressed polycomb, and weak 


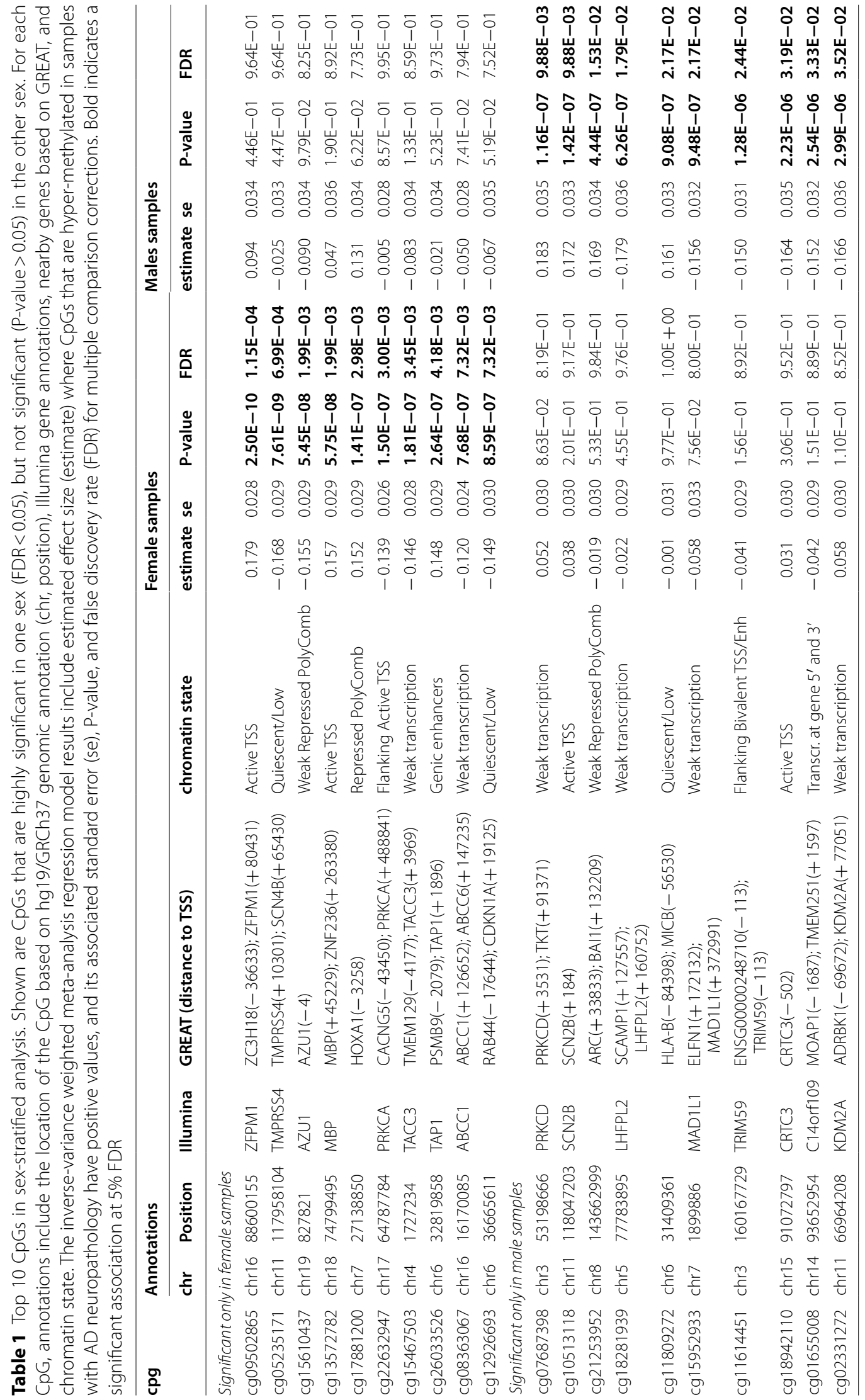




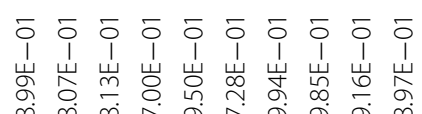

กิ กิ กิ กิ

岁岕岕菂岕

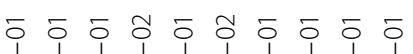

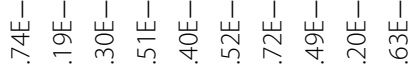

8 능 능 능 웅

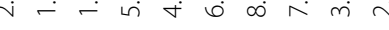

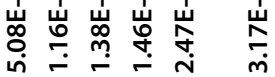

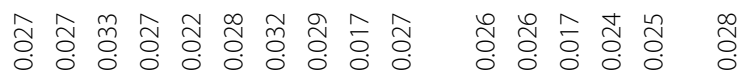

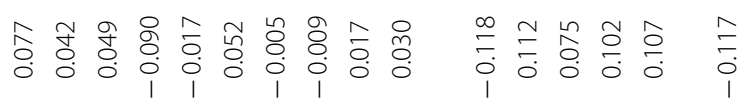

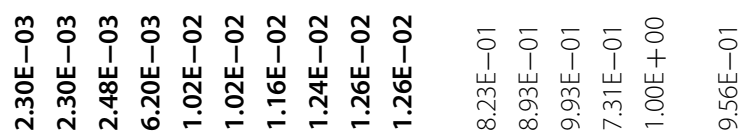

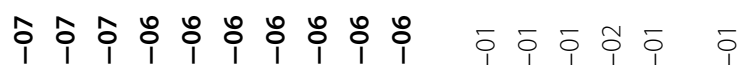

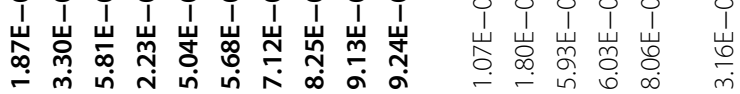

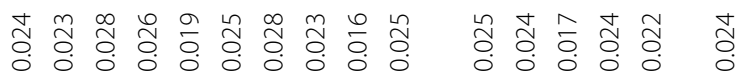

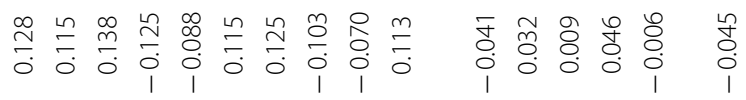

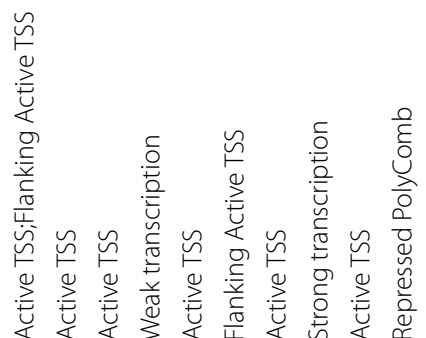

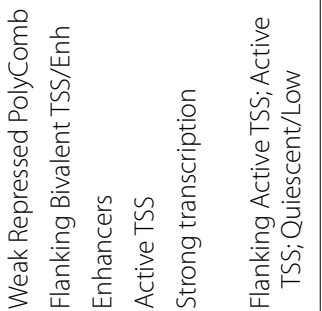

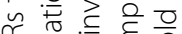

$\sum 0$

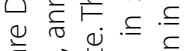

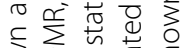

乡 0 ,

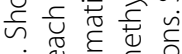

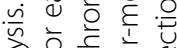

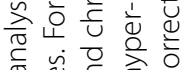

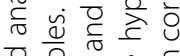

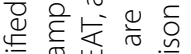

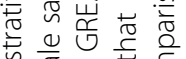

获

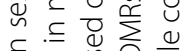

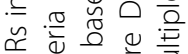

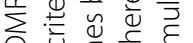

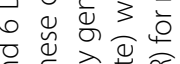

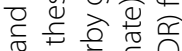

으워월

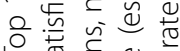

N

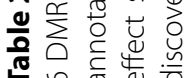
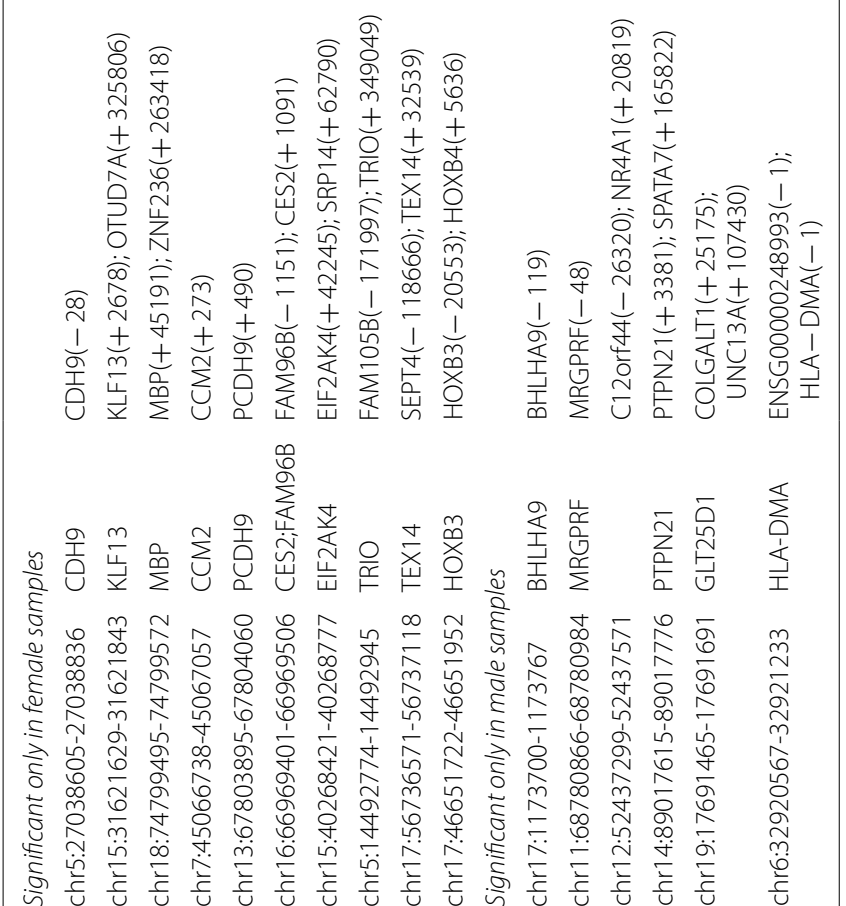


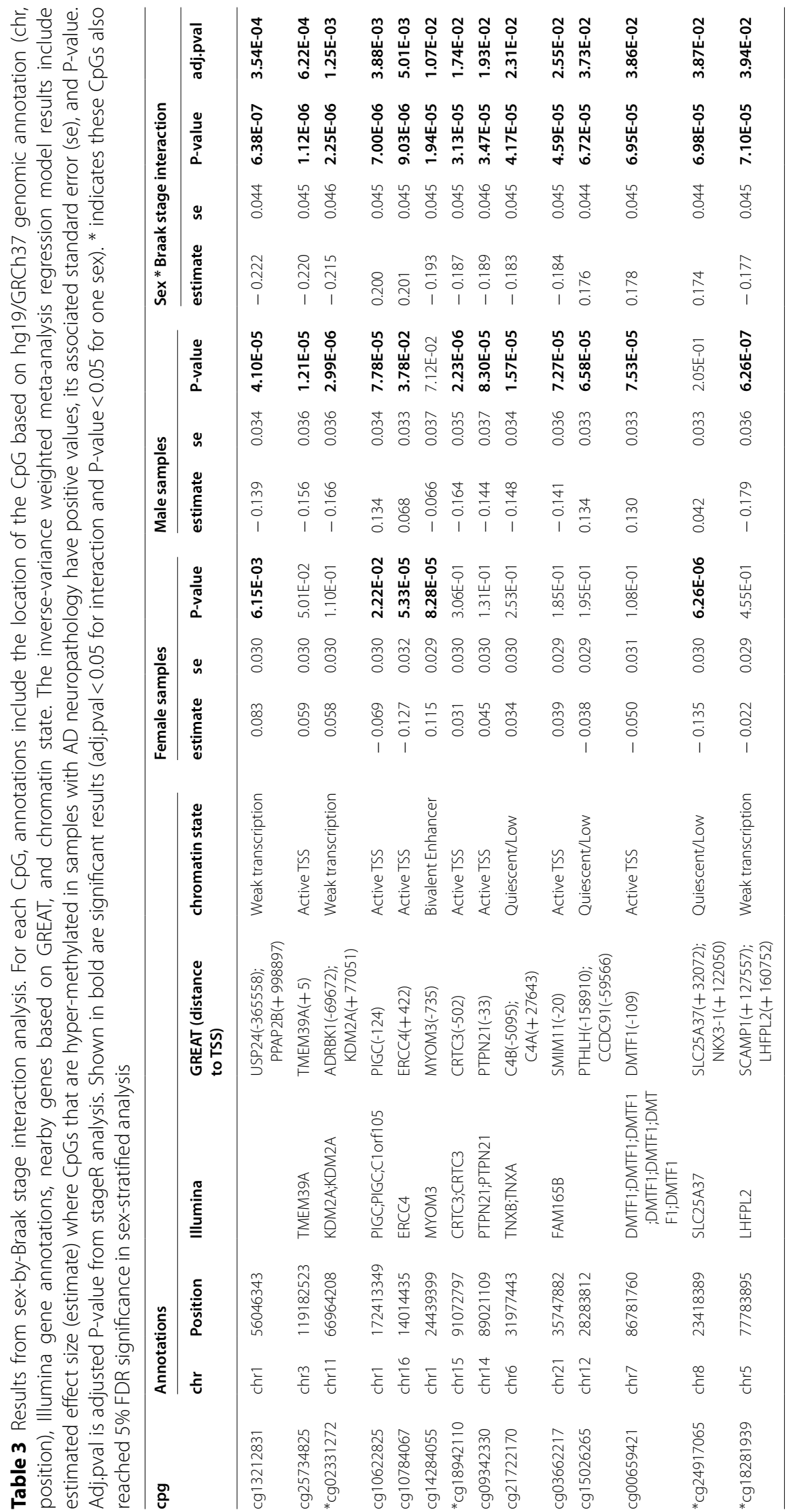




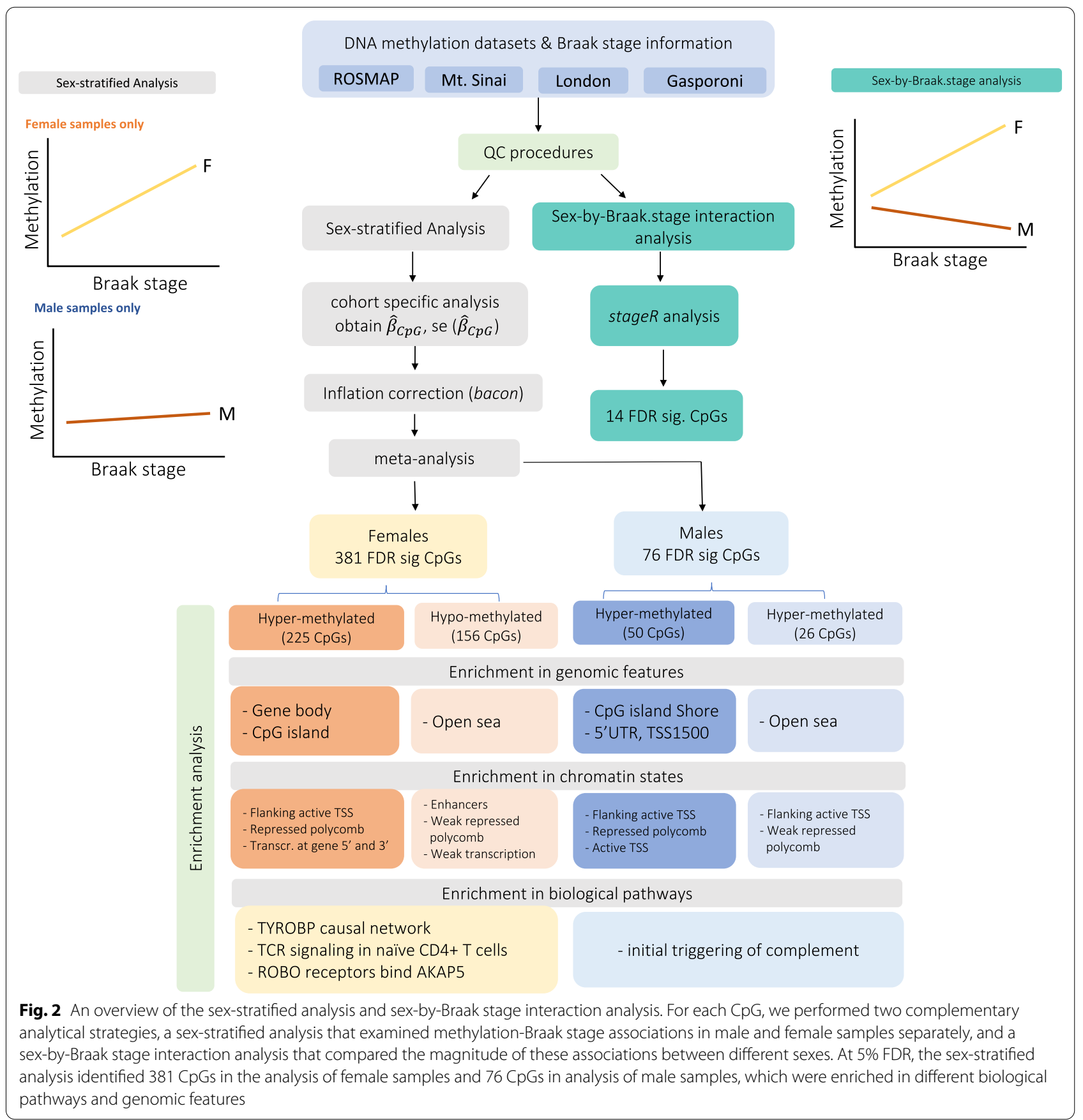

transcription regions, while hypomethylated differences in males were enriched in flanking active TSS and weak repressed polycomb regions (Additional file 1: Fig. S3d, Additional file 2: Table S8). Notably, the enrichment of hypermethylated differences in repressed polycomb regions in both female and male samples is consistent with our previous sex-combined meta-analysis, which also highlighted the enrichment of hyper-methylated Braak-associated DNA methylation differences in polycomb repressed regions [22].
Similarly, enrichment tests for regulatory elements using the LOLA software also supported the potential functional relevance of these significant differences in DNA methylation. Significant DMRs and CpGs in females and males were both enriched in binding sites of EZH2 and SUZ12 (Additional file 2: Table S9), which are subunits of polycomb repressive complex 2 (PRC2), consistent with the observed enrichment of methylation differences in PRC2 repressed regions (Additional file 1: 
Fig. S3c) and previous observations that DNA methylation often interact with PRC2 binding [52, 53]. PRC2 is a type of polycomb group (PcG) protein and plays important roles in multiple biological processes including proliferation and differentiation as well as maintenance of cellular identity through regulation of gene expression. Of particular relevance to AD, PRC2 silences genes involved in neurodegeneration and its deficiency leads to the de-repression of developmental regulators such as the Hox gene clusters, which manifest in progressive and fatal neurodegeneration in mice [54].

\section{Gene ontology and pathway analysis}

Because of the relatively smaller number of gene sets being tested, a 25\% FDR significance threshold, instead of the conventional 5\% FDR, was suggested for GSEA [55]. At 25\% FDR, the significant DNA methylation differences in females were enriched in TYROBP causal network (FDR $=0.014)$, TCR signaling in naïve $C D 4+T$ cells $(\mathrm{FDR}=0.130)$ and $\mathrm{ROBO}$ receptors bind AKAP5 $(\mathrm{FDR}=0.160)$ gene sets, and significant methylation differences in males were enriched in the initial triggering of complement gene set $(\mathrm{FDR}=0.245)$. The TYROBP causal network was previously inferred from a large-scale network analysis of human late-onset $\mathrm{AD}$ brains [56]; it was FDR significant (P-value $<0.001, F D R=0.014$ ) in females (Additional file 1: Fig. S4a), compared to a nominal association in males (P-value $<0.001, F D R=0.620)$. Interestingly, the core enrichment subset of genes identified by GSEA in the female and male networks regulated by TYROBP involved DNA methylation differences at different genes (Additional file 1: Fig. S4b), highlighting different regulatory mechanisms for this gene network in males and females.

The comparison with gene ontology (GO) terms showed at 25\% FDR, significant methylation differences in females were enriched in $25 \mathrm{GO}$ biological processes (Table 4, Additional file 2: Table S10), many of which are involved in inflammatory responses associated with AD pathology including CD 8 positive alpha beta $T$ cell activation and interferon alpha production, as well as other biological processes critical for AD pathogenesis such as response to platelet derived growth factor and positive regulation of axon extension. For males, we did not identify any significant GO terms at 25\% FDR; the strongest enrichment with nominal P-value less than 0.001 involved immune responses to the accumulation of amyloid- $\beta(A \beta)$ in the brain, such as regulation of $\mathrm{T}$ cell activation via $\mathrm{T}$ cell receptor contact with antigen bound to MHC molecule on antigen presenting cell, and other biological processes recently implicated in $\mathrm{AD}$ such as response to angiotensin $[57,58]$ and cell redox homeostasis $[59,60]$.

\section{Correlation of sex-specific DNA methylation differences in $A D$ neuropathology with expression levels of nearby genes}

At 5\% FDR, among FDR significant CpGs in females, all 381 CpGs were linked to a nearby gene by GREAT software, in which 14 were significantly associated with target gene expression levels (Additional file 2: Table S11), and half of them $(n=7)$ had effects in the negative direction. Among FDR significant CpGs in males, out of the 46 CpGs that were linked to a nearby gene, 2 were significantly associated with target gene expression and both were in the negative direction. Notably, in females, several of the most significant CpG methylation-gene expression associations were observed for the $H L A$ $D P A 1$ gene, which encodes microglia receptors involved in antigen presentation and is regulated by PU.1 [61]. In males, the most significant CpG-gene expression was for HLA-DRB1, another PU.1 target gene [61]. For the 14 CpGs identified by our sex-by-Braak stage interaction analysis, only one CpG (cg24917065) was significantly associated with target gene (SLC25A37) expressions.

\section{Correlation and overlap of sex-specific DNA methylation differences in AD neuropathology with genetic susceptibility loci}

To evaluate if the significant methylation differences are located in the vicinity of sex-specific genetic variants implicated in AD, we compared our sex-specific CpGs and DMRs with the recently identified sex-specific SNPs associated with AD biomarkers [62] or AD pathology [63]. We found only 5 CpGs, mapped to the SERP2, KCNE1, TNKS1BP1, FAM165B, PLCB4 genes were located within $500 \mathrm{~kb}$ of the sex-specific SNPs (Additional file 2: Table S12).

To search for mQTLs, which are genetic variants associated with DNA methylations, we next tested associations between the sex-specific CpGs and DMRs with SNPs that are located within $500 \mathrm{~kb}$ from them using 434 female samples, 254 male samples from the ROSMAP study, which had both genotype and DNA methylation data. While no mQTL-DMR pairs reached 5\% FDR significance, we did identify 572 and 284 FDR-significant mQTL-CpG pairs associated with the sex-specific CpGs in females and males, respectively (Additional file 2: Tables S13, S14). Among the 381 and 76 sex-specific CpGs identified in female and male samples, respectively, $41(11 \%)$ and $15(20 \%)$ had at least one corresponding mQTL in brain samples. Among the 14 CpGs identified in our sex-by-Braak stage interaction analysis, 2 and 7 CpGs with at least one brain $\mathrm{mQTL}$, corresponding to 21 and 236 significant mQTL-CpG pairs, were identified at 5\% FDR in females and males, respectively (Additional file 2: Table S15). These mQTL-CpG pairs point to 
important potential molecular mechanisms of diseaseassociated genetic variants that might due, at least in part, to their influences on DNA methylations, which can be further validated in mechanistic studies.

\section{Drug target analysis of sex-specific DNA methylation differences}

To investigate the clinical impact of the sex-specific DNA methylation differences, we next compared them with targets of drugs in the ChEMBL database [48] that are annotated to Alzheimer's disease, many of which are antipsychotic medications commonly prescribed to AD patients for treating psychiatric symptoms that accompany $\mathrm{AD}$. We found that $13 \mathrm{CpGs}$ and 2 DMRs, mapped to 20 genes, had overlap with targets of 16 different drugs (Additional file 2: Table S16). Among them, CACNA1C encodes a voltage-dependent calcium channel, which is a target of cholinesterase inhibitor donepezil. Previously, drug responses for donepezil were shown to be modulated by the sex hormone estrogen receptor alpha (ESR1) genotype [64]. Several CpGs and one DMR are mapped to targets of valproic acid, a mood stabilizer often prescribed for AD patients and was shown to have different pharmacokinetic profiles between male and female subjects [65]. Interestingly, two CpGs and 1 DMR also mapped to targets of caffeine, which was included in cocktail therapy in AD clinical trials $[66,67]$. Although caffeine reduces the risk for $\mathrm{AD}[68,69]$ in both men and women, the protective effect seems to be greater in women [70]. Also, CHRM3 encodes muscarinic acetylcholine receptor, which is targeted by two commonly prescribed antipsychotic drugs for AD patients, trazodone and haloperidol. In both human and animal models, it has been observed treatment with haloperidol induces sex-specific DNA methylation differences [71, 72]. While this study could not establish the mechanisms at which DNA methylation interacts with drugs that AD patients take, we hypothesize that these might include the influence of DNA methylation on drug responses or the differences in DNA methylation resulted from drug actions.

\section{Discussion}

To identify sex-specific differences in AD neuropathology, we performed a sex-stratified analysis and a sex-byBraak stage interaction analysis for each cohort and then used a meta-analysis strategy to combine the cohort-specific association signals. In the sex-stratified analysis, as discussed above, a substantial number of the significant loci showed the same direction but attenuation of effect size for methylation-Braak stage association in a different sex (Tables 1, 2). Therefore, it is not surprising that many of these significant CpGs were identified previously in sex-combined meta-analysis [22]. Among FDR significant methylation differences in females, 325 CpGs (85\%) and 40 DMRs (56\%), mapped to genes such as $H O X A 3, A Z U 1$, and $M B P$ were also previously identified in our sex-combined meta-analysis [22] (Additional file 2: Tables S3, S5). Similarly, in the analysis of male samples, among FDR significant differences, 58 (76\%) CpGs and 15 DMRs (56\%), mapped to genes such as MAMSTR, $R H B D F 2$, and $A G A P 2$, overlapped with significant hits from sex-combined meta-analysis [22] (Additional file 2: Tables S4 and S6). However, our sex-specific analysis provided the new insight that the effects of these known AD genes appear to be predominately driven by effects in only one sex (Tables 1,2).

On the other hand, our sex-specific analysis also uncovered novel methylation differences at $84 \mathrm{CpGs}$ and 42 DMRs that were not identified previously by sex-combined analyses [22], which may had reduced power due to heterogeneity between the sexes. For example, among the top $10 \mathrm{CpGs}$ in the sex-stratified analysis (Table 1), a new locus at cg22632947, which mapped to the gene body of the PRKCA gene, was highly significant in female samples $\quad\left(\right.$ estimate $=-0.139, \quad \mathrm{P}$-value $=1.50 \times 10^{-7}$, $\left.\mathrm{FDR}=3.00 \times 10^{-3}\right)$, but not significant in male samples (estimate $=-0.005, \mathrm{P}$-value $=0.857, \quad \mathrm{FDR}=0.995$ ) (Additional file 1: Fig. S5). The PRKCA gene encodes protein kinase $\mathrm{C} \alpha(\mathrm{PKC} \alpha)$, which participates in synaptic loss resulting from the accumulation of amyloid- $\beta$ $(\mathrm{A} \beta)$ in $\mathrm{AD}$ neuropathology $[73,74]$. Another novel locus is at cg18942110 in the promoter of the CRTC3 gene, where methylation-Braak stage association was highly significant in male samples (estimate $=-0.164$, P-value $\left.=2.23 \times 10^{-6}, \quad \mathrm{FDR}=3.19 \times 10^{-2}\right), \quad$ but not significant in female samples (estimate $=-0.031$, $\mathrm{P}$-value $=0.306, \mathrm{FDR}=0.952$ ) (Additional file 1: Fig. S5). CRTC3 is a member of the CRTC family, which are coactivators of the transcription factor CREB (cAMPresponse element binding protein). In addition to its crucial role in maintaining synaptic plasticity and facilitation of short-term memory to long-term memory, the CREB signaling pathway also mediates synapse loss induced by $\mathrm{A} \beta$ in $\mathrm{AD}$ [75]. Notably, synapse loss significantly correlates with cognitive impairment $[76,77]$ and has been observed to be an early feature of AD pathogenesis [78, 79].

The sex-by-Braak stage interaction analysis also uncovered several additional novel methylation loci that affected AD neuropathology in a sex-specific manner. Notably, none of the $14 \mathrm{CpGs}$ detected in our interaction analysis was identified in previous large-scale DNA methylation studies [18-22], suggesting that sex-specific differences such as these can be missed by conventional studies that do not consider the impact of sex. This is likely due to the cancelation of effects in sex-combined 
analysis because the majority of these 14 CpGs had different directions of methylation-Braak stage effects in male and female samples (Table 3). Among genes mapped to these 14 CpGs, TMEM39A is a member of the transmembrane (TMEM) protein family. In recent GWAS, a genetic variant on TMEM39A was discovered and replicated as an important risk locus for multiple sclerosis, an autoimmune condition of the central nervous system $[80,81]$. While relatively little is known about the role of TMEM39A in AD, given its important contributions to inflammation, dysregulated type I interferon responses, and other immune processes [82] which are also implicated in $\mathrm{AD}$, methylation differences affecting this gene are particularly relevant. Another noteworthy gene is $T N X B$ and its pseudogene TNXA, which are located in the major histocompatibility complex (MHC) class III region on chromosome 6. TNXB encodes tenascin proteins, which are extracellular matrix glycoproteins demonstrated to modulate synaptic plasticity in the brain [83]. In particular, genetic variants at the $H L A-D Q B 1$ locus discovered in the recent $\mathrm{AD}$ genetic meta-analysis [84] included eQTLs for TNXB/TNXA in brain tissues $[84,85]$.

Consistent with previous studies $[18,19,86,87]$, we observed the majority of these sex-specific differences were hyper-methylated in samples with $\mathrm{AD}$ neuropathology, for which methylation levels increased as the AD Braak stage increased (Additional file 2: Tables S17, S18). More specifically, $59 \%$ of the significant CpGs and $69 \%$ of the significant DMRs in females, along with $66 \%$ of the significant CpGs and $89 \%$ of the significant DMRs in males were hyper-methylated in samples with $\mathrm{AD}$ neuropathology (Additional file 2: Tables S3-S6).

To better understand the relevance of these Braakassociated sex-specific differences, we also compared our results with several previous studies. The comparison with Xia et al. [16] and Xu et al. [17], which examined differential methylation between males and females in the prefrontal cortex, but without considering AD neuropathology $[16,17]$, showed our results were largely distinct. Among 451 unique CpGs identified in our sex-stratified analysis or sex-by-Braak stage interaction analysis, only 16 were also identified in Xia et al. [16] and none were identified in Xu et al. [17] (Additional file 2: Tables S3S6). This is probably due to different hypotheses tested in our study and the sexual dimorphism studies - while our study examined the impact of sex on methylationBraak stage association, the previous studies examined differential methylation between the sexes, regardless of AD neuropathology. The comparison of our results with sex-specific DNA methylation differences in fetal brain development $[88,89]$ also showed very little overlap (Additional file 2: Table S19); one hypothesis could be that the Braak-associated sex-specific DNA methylation differences identified in this study might be influenced by environmental risk factors for $\mathrm{AD}$, such as diet and exercise.

The results of our gene set analysis highlighted a number of critical sex-specific biological processes in AD neuropathology. Notably, the TYROBP causal network reached the FDR significance threshold in females $(F D R=0.014)$ but was only nominally significant in males. Interestingly, Braak-associated CpG methylation differences that drove pathway associations (core enrichment genes) occurred at different genes in females and males (Additional file 1: Fig. S4), indicating a potentially sex-specific regulatory mechanism for this network. TYROBP (TYRO protein tyrosine kinase-binding protein) is a key regulator of the complement pathway in the immune/microglia network, which is activated as $\mathrm{A} \beta$ accumulates in LOAD brains [56, 90]. TYROBP is a transmembrane adaptor protein for TREM2, SIRP $\beta 1$, and CR3 receptors, which are known to be involved in AD pathogenesis [90-92]. Also, TYROBP is regulated by SPI1, a central hub for the network of genes involved in myeloid immune response in neurodegeneration [93]. In patients with LOAD, TYROBP was observed to be up-regulated in the brains in multiple cohorts [56]. Recent studies suggested TYROBP-mediated signaling is involved in multiple important functions as aggregating $\mathrm{A} \beta$ activates microglia, including enhanced phagocytosis of damaged neurons $[56,90]$ and suppression of inflammatory responses [94], as well as neuronal pruning activity [56]. Interestingly, in gene ontology (GO) analysis, among the most significant GO Biological Process terms $(P$-value $<0.001)$ in females and males, none of them overlapped (Additional file 2: Table S10), even though the relevancy of all the top biological processes were supported by recent AD literature (Table 4). These results suggest different biological processes are associated with AD pathology in males and females.

Importantly, a number of these sex-specific biological processes pointed to important potential biomarkers and therapeutic targets for the treatment of AD. For example, one of the top biological processes enriched with significant methylation differences in female samples is response to platelet derived growth factor. Recently, multiple studies have shown that reduced levels of plateletderived growth factors (PDGFs) in plasma significantly correlate with mild cognitive impairment and have proposed PDGFs as a potential biomarker for AD $[95,96]$. For the significant methylation differences in male samples, one of the top biological processes highlighted by our enrichment analysis is dysregulation in the complement system. Recently, a number of novel agents targeting the complement system are being developed and 
Table 4 Top 10 most significant GO Biological processes enriched with sex-specific DNA methylation differences associated with AD Braak stage in females and males. Shown are GSEA results including the number of genes in the gene set (SIZE), normalized enrichment score (NES), P-value, FDR, and relevant AD literature for the gene set

\begin{tabular}{|c|c|c|c|c|c|}
\hline Gene Set & SIZE & NES & P-value & FDR & Relevance to AD \\
\hline \multicolumn{6}{|l|}{ Top 10 GO Biological Process terms in females } \\
\hline INTEGRIN_ACTIVATION & 24 & 2.105 & 0 & $9.53 \mathrm{E}-02$ & Wennstrome et al. [98] \\
\hline RESPONSE_TO_PLATELET_DERIVED_GROWTH_FACTOR & 19 & 2.116 & 0 & $1.07 \mathrm{E}-01$ & Sil et al. [99] \\
\hline I_KAPPAB_PHOSPHORYLATION & 19 & 2.081 & 0 & $1.13 \mathrm{E}-01$ & Jha et al. [100] \\
\hline NEGATIVE_REGULATION_OF_INTERLEUKIN_8_PRODUCTION & 18 & 2.133 & 0 & $1.21 \mathrm{E}-01$ & Qin et al. [101] \\
\hline POSITIVE_REGULATION_OF_MACROPHAGE_MIGRATION & 25 & 2.048 & 0 & $1.46 \mathrm{E}-01$ & Bacher et al. [102] \\
\hline TOLL_LIKE_RECEPTOR_SIGNALING_PATHWAY & 142 & 2.031 & 0 & $1.61 \mathrm{E}-01$ & Fiebich et al. [103] \\
\hline $\begin{array}{l}\text { NEGATIVE_REGULATION_OF_TUMOR_NECROSIS_FACTOR_SUPERFAMILY_CYTOKINE_ } \\
\text { PRODUCTION }\end{array}$ & 57 & 2.007 & 0 & $1.90 \mathrm{E}-01$ & Chang et al. [104] \\
\hline REGULATION_OF_SYNCYTIUM_FORMATION_BY_PLASMA_MEMBRANE_FUSION & 28 & 1.944 & 0 & $1.98 \mathrm{E}-01$ & Armoto et al. [105] \\
\hline RESPONSE_TO_VITAMIN_A & 19 & 1.945 & 0 & $2.08 \mathrm{E}-01$ & Ono et al. [106] \\
\hline POSITIVE_REGULATION_OF_AXON_EXTENSION & 42 & 1.931 & 0 & $2.08 \mathrm{E}-01$ & Kanaan et al. [107] \\
\hline \multicolumn{6}{|l|}{ Top 10 Biological Process terms in males } \\
\hline $\begin{array}{l}\text { REGULATION_OF_T_CELL_ACTIVATION_VIA_T_CELL_RECEPTOR_CONTACT_WITH_ANTI- } \\
\text { GEN_BOUND_TO_MHC_MOLECULE_ON_ANTIGEN_PRESENTING_CELL }\end{array}$ & 6 & 1.869 & 0 & $5.98 \mathrm{E}-01$ & Schetters et al. [108] \\
\hline $\begin{array}{l}\text { REGULATION_OF_SYSTEMIC_ARTERIAL_BLOOD_PRESSURE_BY_CIRCULATORY_RENIN_ } \\
\text { ANGIOTENSIN }\end{array}$ & 18 & 1.964 & 0 & $6.11 \mathrm{E}-01$ & Cosarderelioglu et al. [57] \\
\hline NEGATIVE_REGULATION_OF_REACTIVE_OXYGEN_SPECIES_BIOSYNTHETIC_PROCESS & 29 & 1.745 & 0 & $6.12 \mathrm{E}-01$ & Manoharan et al. [59] \\
\hline COMPLEMENT_ACTIVATION & 68 & 1.741 & 0 & $6.26 \mathrm{E}-01$ & Morgan [97] \\
\hline RESPONSE_TO_ANGIOTENSIN & 26 & 1.746 & 0 & $6.36 \mathrm{E}-01$ & Benigni et al. [58] \\
\hline CELL_REDOX_HOMEOSTASIS & 55 & 1.721 & 0 & $6.49 \mathrm{E}-01$ & Chen et al. [60] \\
\hline PROTEIN_DEMETHYLATION & 28 & 1.832 & 0 & $6.77 \mathrm{E}-01$ & Esposito et al. [109] \\
\hline IMMUNE_RESPONSE_INHIBITING_CELL_SURFACE_RECEPTOR_SIGNALING_PATHWAY & 6 & 1.781 & 0 & $7.02 \mathrm{E}-01$ & Schetters et al. [108] \\
\hline DICARBOXYLIC_ACID_CATABOLIC_PROCESS & 17 & 2.052 & 0 & 7.57E-01 & Griffin et al. [110] \\
\hline GLUTAMINE_FAMILY_AMINO_ACID_METABOLIC_PROCESS & 70 & 1.657 & 0 & $7.75 E-01$ & Conway et al. [111] \\
\hline
\end{tabular}

tested in clinical trials for potential effective therapy for AD [97]. Therefore, clinical trials testing potential treatment for $\mathrm{AD}$ patients might have more power for detecting treatment effects by considering sex and targeting the subgroup with the higher predicted benefit based on patient molecular profiles such as DNA methylation.

There are several limitations for this study. The methylation levels in the studies analyzed here were measured on the bulk prefrontal cortex, which contains a complex mixture of cell types. To reduce confounding effects due to cellular heterogeneities, we included the estimated neuron proportion of each brain sample as a covariate variable in all our analyses. Currently, a challenge with cell-type-specific studies is that they are often limited to smaller sample sizes due to labor-intensive sample preparation procedures and therefore have limited statistical power. Also, we did not identify any CpGs or DMRs from chromosome $\mathrm{X}$, this might suggest that sex differences in $\mathrm{AD}$ neuropathology are not primarily due to chromosome X. Alternatively, the lack of association might also be due to the limited coverage by the $450 \mathrm{k}$ array. Future studies utilizing high throughput sequencing that provides better coverage of the epigenome will help clarify the role of the X chromosome in AD neuropathology. Finally, the associations we identified in this study do not necessarily reflect causal relationships. Future studies that employ longitudinal designs are needed to identify causal changes in DNA methylation as AD initiates and progresses.

In summary, our study highlighted the importance of stratifying on sex and analyzing sex-by-disease interaction in the analysis of DNA methylation data to discover the epigenetic architectures underlying AD neuropathology. Our meta-analysis discovered many novel sex-specific DNA methylation differences consistently associated with the AD Braak stage in multiple studies. Because of cancelation of effects in different directions, or dilution from samples with no effect, these sex-specific effects would be missed by sex-combined analysis. Moreover, for many genes previously linked to $\mathrm{AD}$ neuropathology, our work provided evidence that the DNA methylation differences at these genes were predominately driven by effects in only one sex. 
Our enrichment analysis highlighted divergent biological processes in males and females, which underscored sex-specific regulatory mechanisms involved in $\mathrm{AD}$ neuropathology. Finally, our results also have important implications for precision medicine-many of the sex-specific DNA methylation differences also pointed to important potential AD biomarkers and therapeutic targets, suggesting a pressing need for developing and applying sex-specific treatment strategies for AD.

\section{Supplementary Information}

The online version contains supplementary material available at https://doi. org/10.1186/s40478-021-01177-8.

Additional file 1: Supplementary Figures. Figure S1. Quantile-quantile (QQ) plots of observed and expected distributions of P-values in Gasparoni, London, Mount Sinai, and ROSMAP cohorts. Figure S2. Comparison of methylation-Braak stage associations in female samples and male samples. Figure S3. Enrichment of FDR-significant CpGs and CpGs located within FDR-significant DMRs with positive and negative effect estimates in various genomic features and chromatin states. Figure S4. Gene Set Enrichment of the TYROBP causal network with sex-specific Braak-associated DNA methylation differences. Figure S5. Forest plots for several top CpGs identified in sex-stratified analysis and sex-by-Braak stage interaction analysis.

Additional file 2: Supplementary Tables. Table S1. Sample information of the brain samples datasets included in the meta-analysis. Table S2. Quality control (QC) information on DNA methylation samples and probes for each cohort contributing to this meta-analysis. Table S3. In females, a total of 381 differentially methylated CpGs were significantly associated with the AD Braak stage at 5\% FDR in the meta-analysis of four brain samples cohorts (Gasparoni, London, Mt. Sinai, ROSMAP). Table S4. In males, a total of 76 differentially methylated CpGs were significantly associated with the AD Braak stage at 5\% FDR in the meta-analysis of four brain samples cohorts (Gasparoni, London, Mt. Sinai, ROSMAP). Table S5. In females, at $5 \%$ FDR, a total of 72 co-methylated DMRs were significantly associated with AD Braak stage in the meta-analysis of the four brain samples cohorts. Table S6. In males, at 5\% FDR, a total of 27 co-methylated DMRs were significantly associated with AD Braak stage in the meta-analysis of four brain samples cohorts. Table S7. Enrichment of sex-specific DNA methylation changes in different genomic features. Table S8. Enrichment of sex-specific DNA methylation changes in different chromatin states. Table S9. Enrichment of sex-specific DNA methylation changes in binding sites of transcription factors and chromatin proteins assayed by ENCODE and CODEX projects. Table S10. Results of Gene Set Enrichement analysis of sex-specific CpGs and DMRs in female and males. Table S11. Significant association between sex-specific differences and expression levels of nearby genes. Table S12. The sex-specific CpGs and DMRs located within $500 \mathrm{~kb}$ of sex-specific SNPs associated with AD biomarkers or AD neuropathology. Table S13. mQTLs assoicated with FDR-significant CpGs in females. Table S14. mQTLs assoicated with FDR-significant CpGs in males. Table S15. mQTLs associated with significant CpGs identified by sex-by-Braak stage interaction analysis. Table S16. Sex-specific DNA methylation differences overlapped with AD drug targets in ChEMBL database. Table S17. Average beta values at each Braak stage for significant CpGs identified in female samples. Table S18. Average beta values at each Braak stage for significant CpGs identified in male samples. Table S19. Overlap of Braak-associated sex-specific CpGs and DMRs with sex-specifc DNA methylation changes in fetal development.

\section{Authors' contributions}

L.W., J.Y., E.R.M., L.Z., T.C.S., L.G. designed the computational analysis. L.Z., T.C.S., L.G., M.S., J.C., L.W. analyzed the data. L.W., J.Y., E.R.M, X.C. contributed to the interpretation of the results. L.Z, L.W. wrote the paper, and all authors read and approved the manuscript. L.W. conceived the original idea and supervised the project.

\section{Funding}

This research was supported by US National Institutes of Health grants R21AG060459 (L.W.), R01AG061127 (L.W.), R01AG062634 (E.R.M, L.W.), and R01AG060472 (E.R.M). The ROSMAP study data were provided by the Rush Alzheimer's Disease Center, Rush University Medical Center, Chicago. Data collection was supported through funding by NIA grants P30AG10161, R01AG15819, R01AG17917, R01AG30146, R01AG36836, U01AG32984, U01AG46152, the Illinois Department of Public Health, and the Translational Genomics Research Institute.

\section{Availability of data and materials}

All datasets analyzed in this study are publicly available as described in Additional file 2: Table S1. The Mt. Sinai, London, Gasparoni, and ROSMAP datasets can be accessed from GEO (accessions GSE80970, GSE59685, GSE66351) and Synapse (https://doi.org/10.7303/syn3157275). The scripts for the analysis performed in this study can be accessed at https://github.com/TransBioln foLab/ad-meta-analysis-by-sex.

\section{Declarations}

Ethics approval and consent to participate.

Approval for ROSMAP dataset was obtained through Synapse. The ROSMAP study data were provided by the Rush Alzheimer's Disease Center, Rush University Medical Center, Chicago. Data collection was supported through funding by NIA grants P30AG10161, R01AG15819, R01AG17917, R01AG30146, R01AG36836, U01AG32984, U01AG46152, the Illinois Department of Public Health, and the Translational Genomics Research Institute.

\section{Consent for publication}

Not applicable.

\section{Competing interests}

The authors declare that they have no competing interests.

\section{Author details}

${ }^{1}$ Division of Biostatistics, Department of Public Health Sciences, University of Miami, Miller School of Medicine, Miami, FL 33136, USA. ${ }^{2}$ Dr. John T Macdonald Foundation Department of Human Genetics, University of Miami, Miller School of Medicine, Miami, FL 33136, USA. ${ }^{3}$ John P. Hussman Institute for Human Genomics, University of Miami, Miller School of Medicine, Miami, FL 33136, USA. ${ }^{4}$ Brentwood High School, 5304 Murray Ln, Brentwood, TN 37027, USA. ${ }^{5}$ Sylvester Comprehensive Cancer Center, University of Miami, Miller School of Medicine, Miami, FL 33136, USA.

Received: 9 February 2021 Accepted: 10 April 2021

Published online: 26 April 2021

\section{References}

1. Hurd MD, Martorell P, Delavande A, Mullen KJ, Langa KM (2013) Monetary costs of dementia in the United States. N Engl J Med 368(14):1326-1334

2. Hebert LE, Weuve J, Scherr PA, Evans DA (2013) Alzheimer disease in the United States (2010-2050) estimated using the 2010 census. Neurology 80(19):1778-1783

3. Koran MEI, Wagener M, Hohman TJ, I. Alzheimer's Neuroimaging (2017) Sex differences in the association between AD biomarkers and cognitive decline. Brain Imaging Behav 11(1):205-213

4. Tschanz JT, Corcoran CD, Schwartz S, Treiber K, Green RC, Norton MC, Mielke MM, Piercy K, Steinberg M, Rabins PV, Leoutsakos JM, WelshBohmer KA, Breitner JC, Lyketsos CG (2011) Progression of cognitive, functional, and neuropsychiatric symptom domains in a population cohort with Alzheimer dementia: the Cache County Dementia Progression study. Am J Geriatr Psychiatry 19(6):532-542 
5. Ardekani BA, Convit A, Bachman AH (2016) Analysis of the MIRIAD data shows sex differences in hippocampal atrophy progression. J Alzheimers Dis 50(3):847-857

6. Holland D, Desikan RS, Dale AM, McEvoy LK, I. Alzheimer's Disease Neuroimaging (2013) Higher rates of decline for women and apolipoprotein E epsilon4 carriers. AJNR Am J Neuroradiol 34(12):2287-2293

7. Lin KA, Choudhury KR, Rathakrishnan BG, Marks DM, Petrella JR, Doraiswamy PM, I. Alzheimer's Disease Neuroimaging (2015) Marked gender differences in progression of mild cognitive impairment over 8 years. Alzheimers Dement (N Y) 1(2):103-110

8. Hua X, Hibar DP, Lee S, Toga AW, Jack CR Jr, Weiner MW, Thompson PM (2010) Sex and age differences in atrophic rates: an ADNI study with $n=1368$ MRI scans. Neurobiol Aging 31(8):1463-1480

9. Davis EJ, Broestl L, Abdulai-Saiku S, Worden K, Bonham LW, MinonesMoyano E, Moreno AJ, Wang D, Chang K, Williams G, Garay BI, Lobach I, Devidze N, Kim D, Anderson-Bergman C, Yu GQ, White CC, Harris JA, Miller BL, Bennett DA, Arnold AP, De Jager PL, Palop JJ, Panning B, Yokoyama JS, Mucke L, Dubal DB (2020) A second X chromosome contributes to resilience in a mouse model of Alzheimer's disease. Sci Transl Med 12:558

10. Lapane KL, Gambassi G, Landi F, Sgadari A, Mor V, Bernabei R (2001) Gender differences in predictors of mortality in nursing home residents with AD. Neurology 56(5):650-654

11. Stern Y, Tang MX, Albert MS, Brandt J, Jacobs DM, Bell K, Marder K, Sano M, Devanand D, Albert SM, Bylsma F, Tsai WY (1997) Predicting time to nursing home care and death in individuals with Alzheimer disease. JAMA 277(10):806-812

12. Dunn GA, Morgan CP, Bale TL (2011) Sex-specificity in transgenerational epigenetic programming. Horm Behav 59(3):290-295

13. Menger Y, Bettscheider M, Murgatroyd C, Spengler D (2010) Sex differences in brain epigenetics. Epigenomics 2(6):807-821

14. McCarthy MM, Nugent BM (2015) At the frontier of epigenetics of brain sex differences. Front Behav Neurosci 9:221

15. Burghardt KJ, Pilsner JR, Bly MJ, Ellingrod VL (2012) DNA methylation in schizophrenia subjects: gender and MTHFR 677C/T genotype differences. Epigenomics 4(3):261-268

16. Xia Y, Dai R, Wang $K$, Jiao C, Zhang $C$, Xu Y, Li H, Jing $X$, Chen $Y$, Jiang $Y$, Kopp RF, Giase G, Chen C, Liu C (2019) Sex-differential DNA methylation and associated regulation networks in human brain implicated in the sex-biased risks of psychiatric disorders. Mol Psychiatry

17. Xu H, Wang F, Liu Y, Yu Y, Gelernter J, Zhang H (2014) Sex-biased methylome and transcriptome in human prefrontal cortex. Hum Mol Genet 23(5):1260-1270

18. De Jager PL, Srivastava G, Lunnon K, Burgess J, Schalkwyk LC, Yu L, Eaton ML, Keenan BT, Ernst J, McCabe C, Tang A, Raj T, Replogle J, Brodeur W, Gabriel S, Chai HS, Younkin C, Younkin SG, Zou F, Szyf M, Epstein CB, Schneider JA, Bernstein BE, Meissner A, Ertekin-Taner N, Chibnik LB, Kellis M, Mill J, Bennett DA (2014) Alzheimer's disease: early alterations in brain DNA methylation at ANK1, BIN1, RHBDF2 and other loci. Nat Neurosci 17(9):1156-1163

19. Lunnon K, Smith R, Hannon E, De Jager PL, Srivastava G, Volta M Troakes C, Al-Sarraj S, Burrage J, Macdonald R, Condliffe D, Harries LW, Katsel P, Haroutunian V, Kaminsky Z, Joachim C, Powell J, Lovestone S, Bennett DA, Schalkwyk LC, Mill J (2014) Methylomic profiling implicates cortical deregulation of ANK1 in Alzheimer's disease. Nat Neurosci 17(9):1164-1170

20. Smith RG, Hannon E, De Jager PL, Chibnik L, Lott SJ, Condliffe D, Smith AR, Haroutunian V, Troakes C, Al-Sarraj S, Bennett DA, Powell J, Lovestone S, Schalkwyk L, Mill J, Lunnon K (2018) Elevated DNA methylation across a 48-kb region spanning the HOXA gene cluster is associated with Alzheimer's disease neuropathology. Alzheimer's Dementia 14(12):1580-1588

21. Gasparoni G, Bultmann S, Lutsik P, Kraus TFJ, Sordon S, Vlcek J, Dietinger V, Steinmaurer M, Haider M, Mulholland CB, Arzberger T, Roeber S, Riemenschneider M, Kretzschmar HA, Giese A, Leonhardt H, Walter J (2018) DNA methylation analysis on purified neurons and glia dissects age and Alzheimer's disease-specific changes in the human cortex. Epigenetics Chromatin 11(1):41

22. Zhang L, Silva TC, Young Jl, Gomez L, Schmidt MA, Hamilton-Nelson KL, Kunkle BW, Chen X, Martin ER, Wang L (2020) Epigenome-wide meta-analysis of DNA methylation differences in prefrontal cortex implicates the immune processes in Alzheimer's disease. Nat Commun 11(1):6114

23. Ober C, Loisel DA, Gilad Y (2008) Sex-specific genetic architecture of human disease. Nat Rev Genet 9(12):911-922

24. Brookes ST, Whitely E, Egger M, Smith GD, Mulheran PA, Peters TJ (2004) Subgroup analyses in randomized trials: risks of subgroup-specific analyses; power and sample size for the interaction test. J Clin Epidemiol 57(3):229-236

25. Joehanes R, Just AC, Marioni RE, Pilling LC, Reynolds LM, Mandaviya PR, Guan W, Xu T, Elks CE, Aslibekyan S, Moreno-Macias H, Smith JA, Brody JA, Dhingra R, Yousefi P, Pankow JS, Kunze S, Shah SH, McRae AF, Lohman K, Sha J, Absher DM, Ferrucci L, Zhao W, Demerath EW, Bressler J, Grove ML, Huan T, Liu C, Mendelson MM, Yao C, Kiel DP, Peters A, Wang-Sattler R, Visscher PM, Wray NR, Starr JM, Ding J, Rodriguez CJ, Wareham NJ, Irvin MR, Zhi D, Barrdahl M, Vineis P, Ambatipudi S, Uitterlinden AG, Hofman A, Schwartz J, Colicino E, Hou L, Vokonas PS, Hernandez DG, Singleton AB, Bandinelli S, Turner ST, Ware EB, Smith AK, Klengel T, Binder EB, Psaty BM, Taylor KD, Gharib SA, Swenson BR, Liang L, DeMeo DL, O'Connor GT, Herceg Z, Ressler KJ, Conneely KN, Sotoodehnia N, Kardia SL, Melzer D, Baccarelli AA, van Meurs JB, Romieu I, Arnett DK, Ong KK, Liu Y, Waldenberger M, Deary IJ, Fornage M, Levy D, London SJ (2016) Epigenetic signatures of cigarette smoking. Circ Cardiovasc Genet 9(5):436-447

26. Wang T, Guan W, Lin J, Boutaoui N, Canino G, Luo J, Celedon JC, Chen W (2015) A systematic study of normalization methods for Infinium 450K methylation data using whole-genome bisulfite sequencing data. Epigenetics 10(7):662-669

27. Teschendorff AE, Marabita F, Lechner M, Bartlett T, Tegner J, GomezCabrero D, Beck S (2013) A beta-mixture quantile normalization method for correcting probe design bias in Illumina Infinium $450 \mathrm{k}$ DNA methylation data. Bioinformatics 29(2):189-196

28. Pidsley R, CC YW, Volta M, Lunnon K, Mill J, Schalkwyk LC (2013) A datadriven approach to preprocessing Illumina $450 \mathrm{~K}$ methylation array data. BMC Genomics 14:293

29. Guintivano J, Aryee MJ, Kaminsky ZA (2013) A cell epigenotype specific model for the correction of brain cellular heterogeneity bias and its application to age, brain region and major depression. Epigenetics 8(3):290-302

30. Gomez L, Odom GJ, Young Jl, Martin ER, Liu L, Chen X, Griswold AJ, Gao Z, Zhang L, Wang L (2019) coMethDMR: accurate identification of comethylated and differentially methylated regions in epigenome-wide association studies with continuous phenotypes. Nucleic Acids Res 47(17):e98

31. Devlin B, Roeder K (1999) Genomic control for association studies. Biometrics 55(4):997-1004

32. van Iterson M, van Zwet EW, Consortium B, Heijmans BT (2017) Controlling bias and inflation in epigenome- and transcriptome-wide association studies using the empirical null distribution. Genome Biol 18(1):19

33. Higgins JP, Thompson SG (2002) Quantifying heterogeneity in a metaanalysis. Stat Med 21(11):1539-1558

34. Rice K, Higgins JLT (2018) A re-evaluation of fixed effect(s) meta-analysis. J R Stat Soc A 181:205-227

35. Riley RD, Higgins JP, Deeks JJ (2011) Interpretation of random effects meta-analyses. BMJ 342:d549

36. Van den Berge K, Soneson C, Robinson MD, Clement L (2017) stageR: a general stage-wise method for controlling the gene-level false discovery rate in differential expression and differential transcript usage. Genome Biol 18(1):151

37. Chadwick LH (2012) The NIH Roadmap Epigenomics Program data resource. Epigenomics 4(3):317-324

38. Ernst J, Kellis M (2012) ChromHMM: automating chromatin-state discovery and characterization. Nat Methods 9(3):215-216

39. Yen A, Kellis M (2015) Systematic chromatin state comparison of epigenomes associated with diverse properties including sex and tissue type. Nat Commun 6:7973

40. Davis CA, Hitz BC, Sloan CA, Chan ET, Davidson JM, Gabdank I, Hilton JA, Jain K, Baymuradov UK, Narayanan AK, Onate KC, Graham K, Miyasato SR, Dreszer TR, Strattan JS, Jolanki O, Tanaka FY, Cherry JM (2018) The Encyclopedia of DNA elements (ENCODE): data portal update. Nucleic Acids Res 46(D1):D794-D801 
41. Sanchez-Castillo M, Ruau D, Wilkinson AC, Ng FS, Hannah R, Diamanti E, Lombard P, Wilson NK, Gottgens B (2015) CODEX: a next-generation sequencing experiment database for the haematopoietic and embryonic stem cell communities. Nucleic Acids Res 43(Database issue):D1117-D1123

42. Sheffield NC, Bock C (2016) LOLA: enrichment analysis for genomic region sets and regulatory elements in $\mathrm{R}$ and Bioconductor. Bioinformatics 32(4):587-589

43. Subramanian A, Tamayo P, Mootha VK, Mukherjee S, Ebert BL, Gillette MA, Paulovich A, Pomeroy SL, Golub TR, Lander ES, Mesirov JP (2005) Gene set enrichment analysis: a knowledge-based approach for interpreting genome-wide expression profiles. Proc Natl Acad Sci U S A 102(43):15545-15550

44. McLean CY, Bristor D, Hiller M, Clarke SL, Schaar BT, Lowe CB, Wenger AM, Bejerano G (2010) GREAT improves functional interpretation of cisregulatory regions. Nat Biotechnol 28(5):495-501

45. Wood SN (2001) mgcv: GAMs and Generalized Ridge Regression for R. R News 1(2):20-25

46. McCarthy S, Das S, Kretzschmar W, Delaneau O, Wood AR, Teumer A, Kang HM, Fuchsberger C, Danecek P, Sharp K, Luo Y, Sidore C, Kwong A, Timpson N, Koskinen S, Vrieze S, Scott LJ, Zhang H, Mahajan A, Veldink J, Peters U, Pato C, van Duijn CM, Gillies CE, Gandin I, Mezzavilla M, Gilly A, Cocca M, Traglia M, Angius A, Barrett JC, Boomsma D, Branham K, Breen G, Brummett CM, Busonero F, Campbell H, Chan A, Chen S, Chew E, Collins FS, Corbin $\sqcup$, Smith GD, Dedoussis G, Dorr M, Farmaki AE, Ferrucci L, Forer L, Fraser RM, Gabriel S, Levy S, Groop L, Harrison T, Hattersley A, Holmen OL, Hveem K, Kretzler M, Lee JC, McGue M, Meitinger T, Melzer D, Min JL, Mohlke KL, Vincent JB, Nauck M, Nickerson D, Palotie A, Pato M, Pirastu N, McInnis M, Richards JB, Sala C, Salomaa V, Schlessinger D, Schoenherr S, Slagboom PE, Small K, Spector T, Stambolian D, Tuke M, Tuomilehto J, Van den Berg LH, Van Rheenen W, Volker U, Wijmenga C, Toniolo D, Zeggini E, Gasparini P, Sampson MG, Wilson JF, Frayling T, de Bakker PI, Swertz MA, McCarroll S, Kooperberg C, Dekker A, Altshuler D, Willer C, lacono W, Ripatti S, Soranzo N, Walter K, Swaroop A, Cucca F, Anderson CA, Myers RM, Boehnke M, McCarthy MI, Durbin R (2016) C. Haplotype Reference, A reference panel of 64,976 haplotypes for genotype imputation. Nat Genet 48(10):1279-1283

47. Hannon E, Dempster E, Viana J, Burrage J, Smith AR, Macdonald R, St Clair D, Mustard C, Breen G, Therman S, Kaprio J, Toulopoulou T, Hulshoff Pol HE, Bohlken MM, Kahn RS, Nenadic I, Hultman CM, Murray RM, Collier DA, Bass N, Gurling H, McQuillin A, Schalkwyk L, Mill J (2016) An integrated genetic-epigenetic analysis of schizophrenia: evidence for co-localization of genetic associations and differential DNA methylation. Genome Biol 17(1):176

48. Davies M, Nowotka M, Papadatos G, Dedman N, Gaulton A, Atkinson F, Bellis L, Overington JP (2015) ChEMBL web services: streamlining access to drug discovery data and utilities. Nucleic Acids Res 43(W1):W612-W620

49. Viana J, Hannon E, Dempster E, Pidsley R, Macdonald R, Knox O, Spiers H, Troakes C, Al-Saraj S, Turecki G, Schalkwyk LC, Mill J (2017) Schizophrenia-associated methylomic variation: molecular signatures of disease and polygenic risk burden across multiple brain regions. Hum Mol Genet 26(1):210-225

50. Prasad R, Jho EH (2019) A concise review of human brain methylome during aging and neurodegenerative diseases. BMB Rep 52(10):577-588

51. Heyn H, Li N, Ferreira HJ, Moran S, Pisano DG, Gomez A, Diez J, Sanchez-Mut JV, Setien F, Carmona FJ, Puca AA, Sayols S, Pujana MA, Serra-Musach J, Iglesias-Platas I, Formiga F, Fernandez AF, Fraga MF, Heath SC, Valencia A, Gut IG, Wang J, Esteller M (2012) Distinct DNA methylomes of newborns and centenarians. Proc Natl Acad Sci U S A 109(26):10522-10527

52. Reddington JP, Perricone SM, Nestor CE, Reichmann J, Youngson NA Suzuki M, Reinhardt D, Dunican DS, Prendergast JG, Mjoseng H, Ramsahoye BH, Whitelaw E, Greally JM, Adams IR, Bickmore WA, Meehan RR (2013) Redistribution of H3K27me3 upon DNA hypomethylation results in de-repression of Polycomb target genes. Genome Biol 14(3):R25

53. Brinkman AB, Gu H, Bartels SJ, Zhang Y, Matarese F, Simmer F, Marks H, Bock C, Gnirke A, Meissner A, Stunnenberg HG (2012) Sequential ChIPbisulfite sequencing enables direct genome-scale investigation of chromatin and DNA methylation cross-talk. Genome Res 22(6):1128-1138
54. von Schimmelmann M, Feinberg PA, Sullivan JM, Ku SM, Badimon A, Duff MK, Wang Z, Lachmann A, Dewell S, Ma'ayan A, Han MH, Tarakhovsky A, Schaefer A (2016) Polycomb repressive complex 2 (PRC2) silences genes responsible for neurodegeneration. Nat Neurosci 19(10):1321-1330

55. GSEA/MSigDB Team, GSEA FAQ, 2020. https://software.broadinstitute. org/cancer/software/gsea/wiki/index.php/FAQ\#Why_does_GSEA use_a_false_discovery_rate_.28FDR.29_of_0.25_rather_than_the_ more_classic_0.05.3F. Accessed 24 Nov 2020

56. Zhang B, Gaiteri C, Bodea LG, Wang Z, McElwee J, Podtelezhnikov AA, Zhang C, Xie T, Tran L, Dobrin R, Fluder E, Clurman B, Melquist S, Narayanan M, Suver C, Shah H, Mahajan M, Gillis T, Mysore J, MacDonald ME, Lamb JR, Bennett DA, Molony C, Stone DJ, Gudnason V, Myers AJ, Schadt EE, Neumann H, Zhu J, Emilsson V (2013) Integrated systems approach identifies genetic nodes and networks in late-onset Alzheimer's disease. Cell 153(3):707-720

57. Cosarderelioglu C, Nidadavolu LS, George CJ, Oh ES, Bennett DA, Walston JD, Abadir PM (2020) Brain renin-angiotensin system at the intersect of physical and cognitive frailty. Front Neurosci 14:586314

58. Benigni A, Cassis P, Remuzzi G (2010) Angiotensin II revisited: new roles in inflammation, immunology and aging. EMBO Mol Med 2(7):247-257

59. Manoharan S, Guillemin GJ, Abiramasundari RS, Essa MM, Akbar M, Akbar MD (2016) The role of reactive oxygen species in the pathogenesis of Alzheimer's disease. Parkinson's disease, and Huntington's disease: a mini review. Oxid Med Cell Longev 2016:8590578

60. Chen YY, Wang MC, Wang YN, Hu HH, Liu QQ, Liu HJ, Zhao YY (2020) Redox signaling and Alzheimer's disease: from pathomechanism insights to biomarker discovery and therapy strategy. Biomark Res 8:42

61. Rustenhoven J, Smith AM, Smyth LC, Jansson D, Scotter EL, Swanson MEV, Aalderink M, Coppieters N, Narayan P, Handley R, Overall C, Park TIH, Schweder P, Heppner P, Curtis MA, Faull RLM, Dragunow M (2018) PU.1 regulates Alzheimer's disease-associated genes in primary human microglia. Mol Neurodegener 13(1):44

62. Deming Y, Dumitrescu L, Barnes LL, Thambisetty M, Kunkle B, Gifford KA, Bush WS, Chibnik LB, Mukherjee S, De Jager PL, Kukull W, Huentelman M, Crane PK, Resnick SM, Keene CD, Montine TJ, Schellenberg $\mathrm{GD}$, Haines JL, Zetterberg $\mathrm{H}$, Blennow K, Larson EB, Johnson SC, Albert M, Moghekar A, Del Aguila JL, Fernandez MV, Budde J, Hassenstab J, Fagan AM, Riemenschneider M, Petersen RC, Minthon L, Chao MJ, Van Deerlin VM, Lee VM, Shaw LM, Trojanowski JQ, Peskind ER, Li G, Davis LK, Sealock JM, Cox NJ, Goate AM, Bennett DA, Schneider JA, Jefferson AL, Cruchaga C, Hohman TJ, I. Alzheimer's Disease Neuroimaging, C. Alzheimer Disease Genetics (2018) Sex-specific genetic predictors of Alzheimer's disease biomarkers. Acta Neuropathol 136(6):857-872

63. Dumitrescu L, Barnes LL, Thambisetty M, Beecham G, Kunkle B, Bush WS, Gifford KA, Chibnik LB, Mukherjee S, De Jager PL, Kukull W, Crane PK, Resnick SM, Keene CD, Montine TJ, Schellenberg GD, Deming Y, Chao MJ, Huentelman M, Martin ER, Hamilton-Nelson K, Shaw LM, Trojanowski JQ, Peskind ER, Cruchaga C, Pericak-Vance MA, Goate AM, Cox NJ, Haines JL, Zetterberg H, Blennow K, Larson EB, Johnson SC, Albert M, Bennett DA, Schneider JA, Jefferson AL, Hohman TJ, C. Alzheimer's Disease Genetics, I. the Alzheimer's Disease Neuroimaging (2019) Sex differences in the genetic predictors of Alzheimer's pathology. Brain 142(9):2581-2589

64. Scacchi R, Gambina G, Broggio E, Corbo RM (2014) Sex and ESR1 genotype may influence the response to treatment with donepezil and rivastigmine in patients with Alzheimer's disease. Int J Geriatr Psychiatry 29(6):610-615

65. Ibarra M, Vazquez M, Fagiolino P, Derendorf H (2013) Sex related differences on valproic acid pharmacokinetics after oral single dose. J Pharmacokinet Pharmacodyn 40(4):479-486

66. ClinicalTrials.gov., Drug interaction study with a potential Alzheimer's disease compound. https://clinicaltrials.gov/ct2/show/NCT007267 $26 ? \mathrm{id}=\% 22 \mathrm{NCT} 00692510 \% 22 \mathrm{OR} \% 22 \mathrm{NCT0} 00726726 \% 22 \& \mathrm{draw}=2 \& \mathrm{r}$ ank=1. Accessed 31 Jan 2021

67. ClinicalTrials.gov., Drug interaction study between AZD3480 and cytochrome P450 (Cocktail). https://clinicaltrials.gov/ct2/show/NCT0 0692510?id=\%22NCT00692510\%22OR\%22NCT00726726\%22\&draw $=2 \&$ rank $=2$. Accessed 31 Jan 2021 
68. Driscoll I, Shumaker SA, Snively BM, Margolis KL, Manson JE, Vitolins MZ, Rossom RC, Espeland MA (2016) Relationships between caffeine intake and risk for probable dementia or global cognitive impairment: the women's health initiative memory study. J Gerontol A Biol Sci Med Sci 71(12):1596-1602

69. Kim JW, Byun MS, Yi D, Lee JH, Jeon SY, Jung G, Lee HN, Sohn BK, Lee JY, Kim YK, Shin SA, Sohn CH, Lee DY, Group KR (2019) Coffee intake and decreased amyloid pathology in human brain. Transl Psychiatry $9(1): 270$

70. Jee HJ, Lee SG, Bormate KJ, Jung YS (2020) Effect of caffeine consumption on the risk for neurological and psychiatric disorders: sex differences in human. Nutrients 12(10):3080

71. Shimabukuro M, Jinno Y, Fuke C, Okazaki Y (2006) Haloperidol treatment induces tissue- and sex-specific changes in DNA methylation: a control study using rats. Behav Brain Funct 2:37

72. Shimabukuro M, Sasaki T, Imamura A, Tsujita T, Fuke C, Umekage T, Tochigi M, Hiramatsu K, Miyazaki T, Oda T, Sugimoto J, Jinno Y, Okazaki Y (2007) Global hypomethylation of peripheral leukocyte DNA in male patients with schizophrenia: a potential link between epigenetics and schizophrenia. J Psychiatr Res 41(12):1042-1046

73. Alfonso SI, Callender JA, Hooli B, Antal CE, Mullin K, Sherman MA, Lesne SE, Leitges M, Newton AC, Tanzi RE, Malinow R (2016) Gain-of-function mutations in protein kinase Calpha (PKCalpha) may promote synaptic defects in Alzheimer's disease. Sci Signal 9(427):ra47

74. John A, Reddy PH (2020) Synaptic basis of Alzheimer's disease: Focus on synaptic amyloid beta. P-tau and mitochondria. Ageing Res Rev 65:101208

75. Saura CA, Valero J (2011) The role of CREB signaling in Alzheimer's disease and other cognitive disorders. Rev Neurosci 22(2):153-169

76. DeKosky ST, Scheff SW (1990) Synapse loss in frontal cortex biopsies in Alzheimer's disease: correlation with cognitive severity. Ann Neurol 27(5):457-464

77. Terry RD, Masliah E, Salmon DP, Butters N, DeTeresa R, Hill R, Hansen LA, Katzman R (1991) Physical basis of cognitive alterations in Alzheimer's disease: synapse loss is the major correlate of cognitive impairment. Ann Neurol 30(4):572-580

78. Masliah E, Mallory M, Alford M, DeTeresa R, Hansen LA, McKeel DW Jr, Morris JC (2001) Altered expression of synaptic proteins occurs early during progression of Alzheimer's disease. Neurology 56(1):127-129

79. Scheff SW, Price DA, Schmitt FA, DeKosky ST, Mufson EJ (2007) Synaptic alterations in CA1 in mild Alzheimer disease and mild cognitive impairment. Neurology 68(18):1501-1508

80. C. International Multiple Sclerosis Genetics (2010) Comprehensive follow-up of the first genome-wide association study of multiple sclerosis identifies KIF21B and TMEM39A as susceptibility loci. Hum Mol Genet 19(5): 953-962

81. Varade J, Comabella M, Ortiz MA, Arroyo R, Fernandez O, Pinto-Medel MJ, Fedetz M, Izquierdo G, Lucas M, Gomez CL, Rabasa AC, Alcina A, Matesanz F, Alloza I, Antiguedad A, Garcia-Barcina M, Otaegui D, Olascoaga J, Saiz A, Blanco Y, Montalban X, Vandenbroeck K, Urcelay E (2012) Replication study of 10 genes showing evidence for association with multiple sclerosis: validation of TMEM39A, IL12B and CBLB [correction of CLBL] genes. Mult Scler 18(7):959-965

82. Tran Q, Park J, Lee H, Hong Y, Hong S, Park S, Park J, Kim SH (2017) TMEM39A and human diseases: a brief review. Toxicol Res 33(3):205-209

83. Ferrer-Ferrer M, Dityatev A (2018) Shaping synapses by the neural extracellular matrix. Front Neuroanat 12:40

84. Kunkle BW, Grenier-Boley B, Sims R, Bis JC, Damotte V, Naj AC, Boland A, Vronskaya M, van der Lee SJ, Amlie-Wolf A, Bellenguez C, Frizatti A, Chouraki V, Martin ER, Sleegers K, Badarinarayan N, Jakobsdottir J, Hamilton-Nelson KL, Moreno-Grau S, Olaso R, Raybould R, Chen Y, Kuzma AB, Hiltunen M, Morgan T, Ahmad S, Vardarajan BN, Epelbaum J, Hoffmann P, Boada M, Beecham GW, Garnier JG, Harold D, Fitzpatrick AL, Valladares O, Moutet ML, Gerrish A, Smith AV, Qu L, Bacq D, Denning N, Jian X, Zhao Y, Del Zompo M, Fox NC, Choi SH, Mateo I, Hughes JT, Adams HH, Malamon J, Sanchez-Garcia F, Patel Y, Brody JA, Dombroski BA, Naranjo MCD, Daniilidou M, Eiriksdottir G, Mukherjee S, Wallon D, Uphill J, Aspelund T, Cantwell LB, Garzia F, Galimberti D, Hofer E, Butkiewicz M, Fin B, Scarpini E, Sarnowski C, Bush WS, Meslage S, Kornhuber J, White CC, Song Y, Barber RC, Engelborghs S, Sordon S,
Voijnovic D, Adams PM, Vandenberghe R, Mayhaus M, Cupples LA, Albert MS, De Deyn PP, Gu W, Himali JJ, Beekly D, Squassina A, Hartmann AM, Orellana A, Blacker D, Rodriguez-Rodriguez E, Lovestone S, Garcia ME, Doody RS, Munoz-Fernadez C, Sussams R, Lin H, Fairchild TJ, Benito YA, Holmes C, Karamujic-Comic H, Frosch MP, Thonberg H, Maier W, Roshchupkin G, Ghetti B, Giedraitis V, Kawalia A, Li S, Huebinger RM, Kilander L, Moebus S, Hernandez I, Kamboh MI, Brundin R, Turton J, Yang Q, Katz MJ, Concari L, Lord J, Beiser AS, Keene CD, Helisalmi S, Kloszewska I, Kukull WA, Koivisto AM, Lynch A, Tarraga L, Larson EB, Haapasalo A, Lawlor B, Mosley TH, Lipton RB, Solfrizzi V, Gill M, Longstreth WT Jr, Montine TJ, Frisardi V, Diez-Fairen M, Rivadeneira F, Petersen RC, Deramecourt V, Alvarez I, Salani F, Ciaramella A, Boerwinkle E, Reiman EM, Fievet N, Rotter JI, Reisch JS, Hanon O, Cupidi C, Andre Uitterlinden AG, Royall DR, Dufouil C, Maletta RG, de Rojas I, Sano M, Brice A, Cecchetti R, George-Hyslop PS, Ritchie K, Tsolaki M, Tsuang DW, Dubois B, Craig D, Wu CK, Soininen H, Avramidou D, Albin RL, Fratiglioni L, Germanou A, Apostolova LG, Keller L, Koutroumani M, Arnold SE, Panza F, Gkatzima O, Asthana S, Hannequin D, Whitehead P, Atwood CS, Caffarra P, Hampel H, Quintela I, Carracedo A, Lannfelt L, Rubinsztein DC, Barnes LL, Pasquier F, Frolich L, Barral S, McGuinness B, Beach TG, Johnston JA, Becker JT, Passmore P, Bigio EH, Schott JM, Bird TD, Warren JD, Boeve BF, Lupton MK, Bowen JD, Proitsi P, Boxer A, Powell JF, Burke JR, Kauwe JSK, Burns JM, Mancuso M, Buxbaum JD, Bonuccelli U, Cairns NJ, McQuillin A, Cao C, Livingston G, Carlson CS, Bass NJ, Carlsson CM, Hardy J, Carney RM, Bras J, Carrasquillo MM, Guerreiro R, Allen M, Chui HC, Fisher E, Masullo C, Crocco EA, DeCarli C, Bisceglio G, Dick M, Ma L, Duara R, Graff-Radford NR, Evans DA, Hodges A, Faber KM, Scherer M, Fallon KB, Riemenschneider M, Fardo DW, Heun R, Farlow MR, Kolsch H, Ferris S, Leber M, Foroud TM, Heuser I, Galasko DR, Giegling I, Gearing M, Hull M, Geschwind DH, Gilbert JR, Morris J, Green RC, Mayo K, Growdon JH, Feulner T, Hamilton RL, Harrell LE, Drichel D, Honig LS, Cushion TD, Huentelman MJ, Hollingworth P, Hulette CM, Hyman BT, Marshall R, Jarvik GP, Meggy A, Abner E, Menzies GE, Jin LW, Leonenko G, Real LM, Jun GR, Baldwin CT, Grozeva D, Karydas A, Russo G, Kaye JA, Kim R, Jessen F, Kowall NW, Vellas B, Kramer JH, Vardy E, LaFerla FM, Jockel KH, Lah JJ, Dichgans M, Leverenz JB, Mann D, Levey Al, Pickering-Brown S, Lieberman AP, Klopp N, Lunetta KL, Wichmann HE, Lyketsos CG, Morgan K, Marson DC, Brown K, Martiniuk F, Medway C, Mash DC, Nothen MM, Masliah E, Hooper NM, McCormick WC, Daniele A, McCurry SM, Bayer A, McDavid AN, Gallacher J, McKee AC, van den Bussche H, Mesulam M, Brayne C, Miller BL, Riedel-Heller S, Miller CA, Miller JW, Al-Chalabi A, Morris JC, Shaw CE, Myers AJ, Wiltfang J, O'Bryant S, Olichney JM, Alvarez V, Parisi JE, Singleton AB, Paulson HL, Collinge J, Perry WR, Mead S, Peskind E, Cribbs DH, Rossor M, Pierce A, Ryan NS, Poon WW, Nacmias B, Potter H, Sorbi S, Quinn JF, Sacchinelli E, Raj A, Spalletta G, Raskind M, Caltagirone C, Bossu P, Orfei MD, Reisberg B, Clarke R, Reitz C, Smith AD, Ringman JM, Warden D, Roberson ED, Wilcock G, Rogaeva E, Bruni AC, Rosen HJ, Gallo M, Rosenberg RN, Ben-Shlomo Y, Sager MA, Mecocci P, Saykin AJ, Pastor P, Cuccaro ML, Vance JM, Schneider JA, Schneider LS, Slifer S, Seeley WW, Smith AG, Sonnen JA, Spina S, Stern RA, Swerdlow RH, Tang M, Tanzi RE, Trojanowski JQ, Troncoso JC, Van Deerlin VM, Van Eldik LJ, Vinters HV, Vonsattel JP, Weintraub S, Welsh-Bohmer KA, Wilhelmsen KC, Williamson J, Wingo TS, Woltjer RL, Wright CB, Yu CE, Yu L, Saba Y, Pilotto A, Bullido MJ, Peters O, Crane PK, Bennett D, Bosco P, Coto E, Boccardi V, De Jager PL, Lleo A, Warner N, Lopez OL, Ingelsson M, Deloukas P, Cruchaga C, Graff C, Gwilliam R, Fornage M, Goate AM, Sanchez-Juan P, Kehoe PG, Amin N, Ertekin-Taner N, Berr C, Debette S, Love S, Launer LJ, Younkin SG, Dartigues JF, Corcoran C, Ikram MA, Dickson DW, Nicolas G, Campion D, Tschanz J, Schmidt H, Hakonarson H, Clarimon J, Munger R, Schmidt R, Farrer LA, Van Broeckhoven C, M COD, DeStefano AL, Jones L, Haines JL, Deleuze JF, Owen MJ, Gudnason V, Mayeux R, Escott-Price V, Psaty BM, Ramirez A, Wang LS, Ruiz A, van Duijn CM, Holmans PA, Seshadri S, Williams J, Amouyel P, Schellenberg GD, Lambert JC, Pericak-Vance MA, C. Alzheimer Disease Genetics, I. European Alzheimer's Disease, H. Cohorts for, C. Aging Research in Genomic Epidemiology, Genetic, P. Environmental Risk in Ad/Defining Genetic, C. Environmental Risk for Alzheimer's Disease (2019) Genetic meta-analysis of diagnosed Alzheimer's disease identifies new risk loci and implicates Abeta, tau, immunity and lipid processing. Nat Genet 51(3):414-430 
85. Ramasamy A, Trabzuni D, Guelfi S, Varghese V, Smith C, Walker R, De T, Coin L, de Silva R, Cookson MR, Singleton AB, Hardy J, Ryten M, Weale ME, U.K.B.E. Consortium, C. North American Brain Expression (2014) Genetic variability in the regulation of gene expression in ten regions of the human brain. Nat Neurosci 17(10):1418-1428

86. Watson CT, Roussos P, Garg P, Ho DJ, Azam N, Katsel PL, Haroutunian V, Sharp AJ (2016) Genome-wide DNA methylation profiling in the superior temporal gyrus reveals epigenetic signatures associated with Alzheimer's disease. Genome Med 8(1):5

87. Bakulski KM, Dolinoy DC, Sartor MA, Paulson HL, Konen JR, Lieberman AP, Albin RL, Hu H, Rozek LS (2012) Genome-wide DNA methylation differences between late-onset Alzheimer's disease and cognitively normal controls in human frontal cortex. J Alzheimers Dis 29(3):571-588

88. Spiers H, Hannon E, Schalkwyk LC, Smith R, Wong CC, O'Donovan MC, Bray NJ, Mill J (2015) Methylomic trajectories across human fetal brain development. Genome Res 25(3):338-352

89. Perzel Mandell KA, Price AJ, Wilton R, Collado-Torres L, Tao R, Eagles NJ, Szalay AS, Hyde TM, Weinberger DR, Kleinman JE, Jaffe AE (2021) Characterizing the dynamic and functional DNA methylation landscape in the developing human cortex. Epigenetics 16(1):1-3

90. Ma J, Jiang T, Tan L, Yu JT (2015) TYROBP in Alzheimer's disease. Mol Neurobiol 51(2):820-826

91. Pottier C, Ravenscroft TA, Brown PH, Finch NA, Baker M, Parsons M, Asmann YW, Ren Y, Christopher E, Levitch D, van Blitterswijk M Cruchaga C, Campion D, Nicolas G, Richard AC, Guerreiro R, Bras JT, Zuchner S, Gonzalez MA, Bu G, Younkin S, Knopman DS, Josephs KA, Parisi JE, Petersen RC, Ertekin-Taner N, Graff-Radford NR, Boeve BF, Dickson DW, Rademakers R (2016) TYROBP genetic variants in early-onset Alzheimer's disease. Neurobiol Aging 48:2229-22215

92. Paloneva J, Manninen T, Christman G, Hovanes K, Mandelin J, Adolfsson R, Bianchin M, Bird T, Miranda R, Salmaggi A, Tranebjaerg L, Konttinen Y, Peltonen $L$ (2002) Mutations in two genes encoding different subunits of a receptor signaling complex result in an identical disease phenotype. Am J Hum Genet 71(3):656-662

93. Huang KL, Marcora E, Pimenova AA, Di Narzo AF, Kapoor M, Jin SC, Harari O, Bertelsen S, Fairfax BP, Czajkowski J, Chouraki V, Grenier-Boley B, Bellenguez C, Deming Y, McKenzie A, Raj T, Renton AE, Budde J, Smith A, Fitzpatrick A, Bis JC, DeStefano A, Adams HHH, Ikram MA, van der Lee S, Del-Aguila JL, Fernandez MV, Ibanez L, Sims R, Escott-Price V, Mayeux R, Haines JL, Farrer LA, Pericak-Vance MA, Lambert JC, van Duijn C, Launer L, Seshadri S, Williams J, Amouyel P, Schellenberg GD, Zhang B, Borecki I, Kauwe JSK, Cruchaga C, Hao K, Goate AM, P. International Genomics of Alzheimer's, I. Alzheimer's Disease Neuroimaging (2017) A common haplotype lowers PU1 expression in myeloid cells and delays onset of Alzheimer's disease. Nat Neurosci 20(8):1052-1061

94. Sessa G, Podini P, Mariani M, Meroni A, Spreafico R, Sinigaglia F, Colonna M, Panina P, Meldolesi J (2004) Distribution and signaling of TREM2/ DAP12, the receptor system mutated in human polycystic lipomembraneous osteodysplasia with sclerosing leukoencephalopathy dementia. Eur J Neurosci 20(10):2617-2628
95. Bjorkqvist M, Ohlsson M, Minthon L, Hansson O (2012) Evaluation of a previously suggested plasma biomarker panel to identify Alzheimer's disease. PLoS ONE 7(1):e29868

96. Ray S, Britschgi M, Herbert C, Takeda-Uchimura Y, Boxer A, Blennow K, Friedman LF, Galasko DR, Jutel M, Karydas A, Kaye JA, Leszek J, Miller BL, Minthon L, Quinn JF, Rabinovici GD, Robinson WH, Sabbagh MN, So YT, Sparks DL, Tabaton M, Tinklenberg J, Yesavage JA, Tibshirani R, WyssCoray T (2007) Classification and prediction of clinical Alzheimer's diagnosis based on plasma signaling proteins. Nat Med 13(11):1359-1362

97. Morgan BP (2018) Complement in the pathogenesis of Alzheimer's disease. Semin Immunopathol 40(1):113-124

98. Wennstrom M, Nielsen HM (2012) Cell adhesion molecules in Alzheimer's disease. Degener Neurol Neuromuscul Dis 2:65-77

99. Sil S, Periyasamy P, Thangaraj A, Chivero ET, Buch S (2018) PDGF/PDGFR axis in the neural systems. Mol Aspects Med 62:63-74

100. Jha NK, Jha SK, Kar R, Nand P, Swati K, Goswami VK (2019) Nuclear factor-kappa beta as a therapeutic target for Alzheimer's disease. J Neurochem 150(2):113-137

101. B. Qin, L. Li, S. Wang, J. Wu, Y. Huang, P. Zhou, J. Bai, Y. Zheng, Interleukin-8 gene polymorphism -251T>A contributes to Alzheimer's disease susceptibility, Medicine (Baltimore) 95(39) (2016) e5039.

102. Bacher M, Deuster O, Aljabari B, Egensperger R, Neff F, Jessen F, Popp J, Noelker C, Reese JP, Al-Abed Y, Dodel R (2010) The role of macrophage migration inhibitory factor in Alzheimer's disease. Mol Med 16(3-4):116-121

103. Fiebich BL, Batista CRA, Saliba SW, Yousif NM, de Oliveira ACP (2018) Role of microglia TLRs in neurodegeneration. Front Cell Neurosci 12:329

104. Chang R, Yee KL, Sumbria RK (2017) Tumor necrosis factor alpha Inhibition for Alzheimer's disease. J Cent Nerv Syst Dis 9:1179573517709278

105. Armato U, Chakravarthy B, Pacchiana R, Whitfield JF (2013) Alzheimer's disease: an update of the roles of receptors, astrocytes and primary cilia (review). Int J Mol Med 31(1):3-10

106. Ono K, Yamada M (2012) Vitamin A and Alzheimer's disease. Geriatr Gerontol Int 12(2):180-188

107. Kanaan NM, Pigino GF, Brady ST, Lazarov O, Binder LI, Morfini GA (2013) Axonal degeneration in Alzheimer's disease: when signaling abnormalities meet the axonal transport system. Exp Neurol 246:44-53

108. Schetters STT, Gomez-Nicola D, Garcia-Vallejo JJ, Van Kooyk Y (2017) Neuroinflammation: microglia and T cells get ready to tango. Front Immunol 8:1905

109. Esposito M, Sherr GL (2019) Epigenetic modifications in Alzheimer's neuropathology and therapeutics. Front Neurosci 13:476

110. Griffin JW, Bradshaw PC (2017) Amino acid catabolism in Alzheimer's disease brain: friend or foe? Oxid Med Cell Longev 2017:5472792

111. Conway ME (2020) Alzheimer's disease: targeting the glutamatergic system. Biogerontology 21(3):257-274

\section{Publisher's Note}

Springer Nature remains neutral with regard to jurisdictional claims in published maps and institutional affiliations.

\footnotetext{
Ready to submit your research? Choose BMC and benefit from:

- fast, convenient online submission

- thorough peer review by experienced researchers in your field

- rapid publication on acceptance

- support for research data, including large and complex data types

- gold Open Access which fosters wider collaboration and increased citations

- maximum visibility for your research: over 100M website views per year
}

At $\mathrm{BMC}$, research is always in progress.

Learn more biomedcentral.com/submissions 